
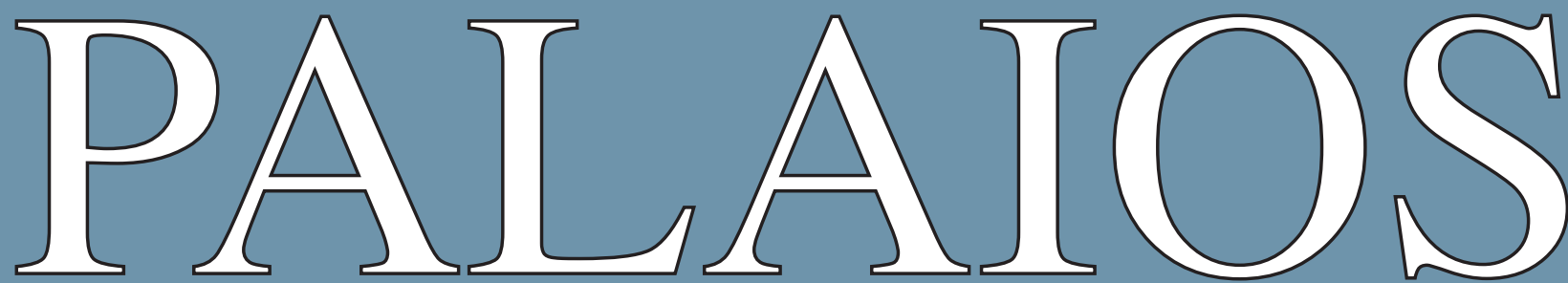

Emphasizing the Impact of Life on Earth's History

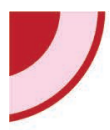

(1) IIIII (n-1) 2. (1) 1.

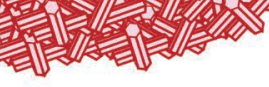
正 (O) 1. 8.

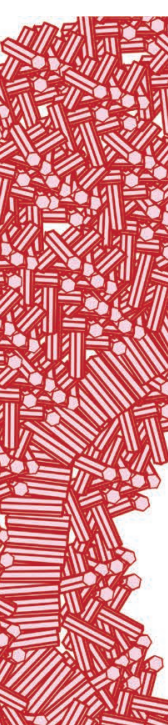

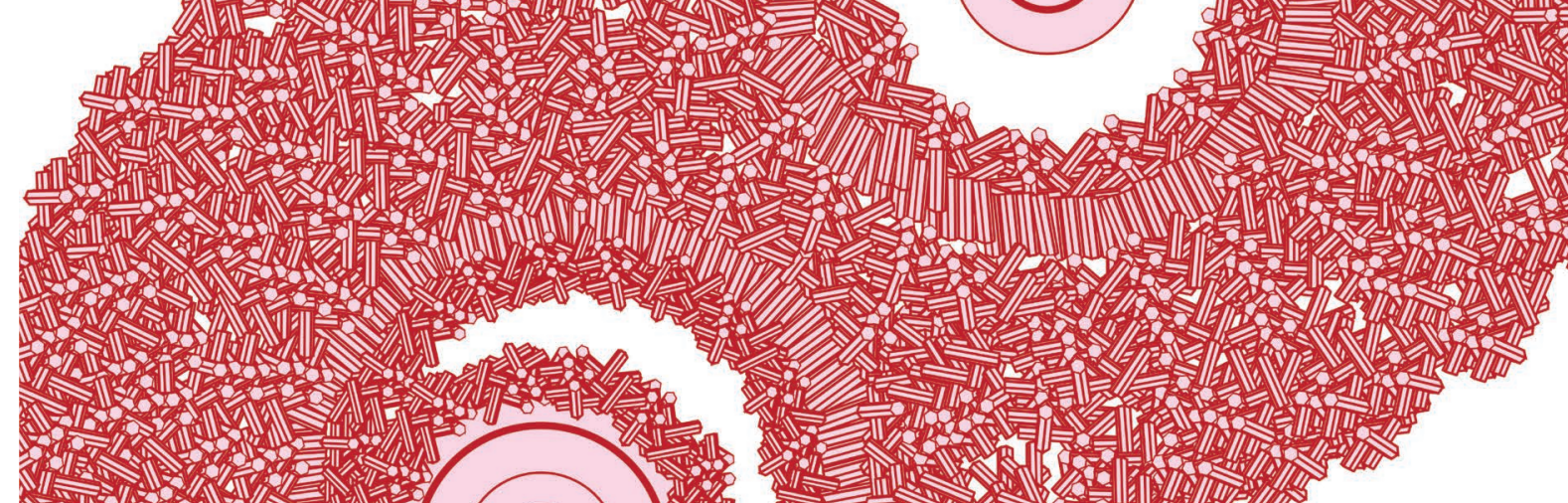

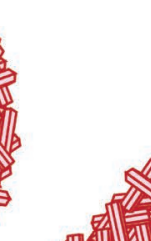
年

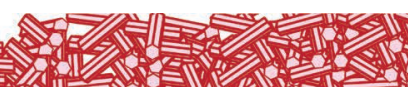

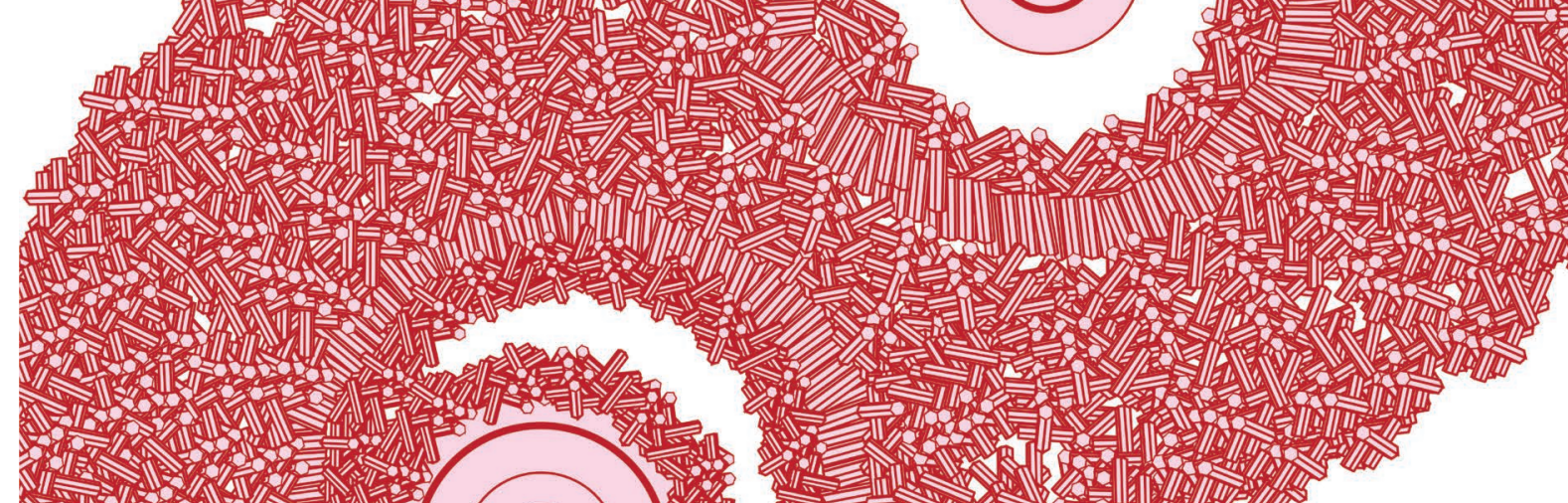
(1) (1)

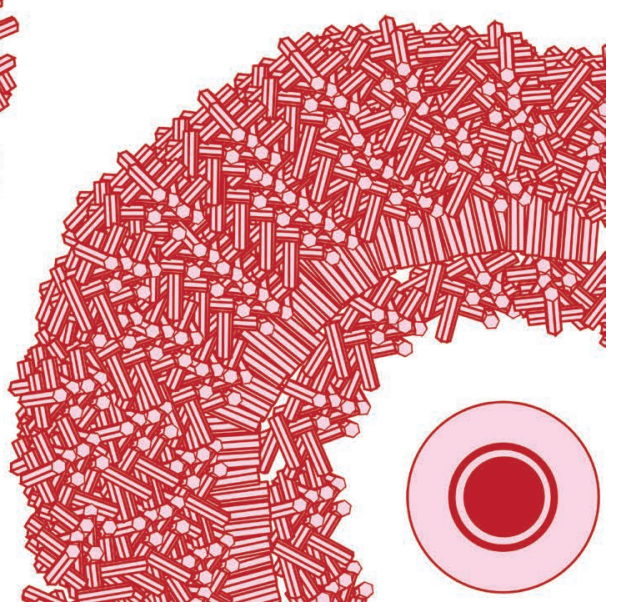



Earth's history

\title{
TAPHONOMY AND BIOLOGICAL AFFINITY OF THREE-DIMENSIONALLY PHOSPHATIZED BROMALITES FROM THE MIDDLE ORDOVICIAN WINNESHIEK LAGERSTÄTTE, NORTHEASTERN IOWA, USA
}

\author{
ANDREW D. HAWKINS, ${ }^{1}$ HUAIBAO P. LIU, ${ }^{2}$ DEREK E. G. BRIGGS, ${ }^{3}$ A D. MUSCENTE,,${ }^{1,4}$ ROBERT M. MCKAY, ${ }^{2}$ BRIAN J. WITZKE, ${ }^{5}$ AND \\ SHUHAI XIAO ${ }^{1}$ \\ ${ }^{1}$ Department of Geosciences, Virginia Tech, Blacksburg, Virginia 24061, USA \\ ${ }^{2}$ Iowa Geological Survey, IIHR-Hydroscience and Engineering, University of Iowa, Iowa City, Iowa 52242, USA \\ ${ }^{3}$ Department of Geology and Geophysics, Yale University, New Haven, Connecticut 06520, USA \\ ${ }^{4}$ Current address: Department of Earth and Planetary Sciences, Harvard University, Cambridge, Massachusetts 02138, USA \\ ${ }^{5}$ Department of Earth and Environmental Sciences, University of Iowa, Iowa City, Iowa 52242, USA \\ email: xiao@vt.edu
}

\begin{abstract}
Aвstract: The Winneshiek Lagerstätte occurs within an Ordovician meteorite impact structure beneath part of the city of Decorah, Iowa. The Lagerstätte has yielded an atypical marine fauna including phyllocarid crustaceans, eurypterids, conodonts, linguloid brachiopods, and jawless fish. Associated with these taxa are vermiform fossils: elongate, morphologically variable, and often three-dimensionally preserved bromalites of uncertain organisms. The preservational state of these bromalites is significantly different from that of other components of the Winneshiek biota. Here we present a compositional and microstructural analysis of the vermiform fossils in order to elucidate their taphonomy and biological affinities. The majority of studied specimens are preserved three-dimensionally and composed of calcium phosphate, while a minority are preserved as carbonaceous compressions. Winneshiek bromalites exhibit important similarities to examples documented from both older and younger sediments. They provide independent evidence of predation in the Winneshiek assemblage during the Great Ordovician Biodiversification Event.
\end{abstract}

\section{INTRODUCTION}

The Winneshiek Lagerstätte in northeastern Iowa was discovered in 2005 (Liu et al. 2006) and represents a rare example of exceptional preservation in the Middle Ordovician (Van Roy et al. 2015; Muscente et al. 2017). Deposited in a previously unrecognized meteorite impact structure (Fig. 1), the Winneshiek Shale - the stratigraphic unit hosting the Winneshiek Lagerstätte - is a spatially restricted green-gray laminated shale that lacks common elements of normal marine Ordovician communities, such as trilobites, graptolites, articulate brachiopods, and bryozoans. Instead, the Winneshiek fauna is dominated by a variety of arthropods, including phyllocarid crustaceans and eurypterids, as well as conodonts, placoderm fishes, and linguloid brachiopods. The Winneshiek fauna is characterized by exceptional preservation, including arthropods preserved as cuticular remains and carbonaceous compressions, and multiple species of conodonts preserved as bedding plane assemblages (Liu et al. 2006, 2017).

Associated with these familiar taxa are three-dimensionally preserved bromalites referred to as "vermiform fossils" by Liu et al. (2006). Bromalites are one of the most common components of the Winneshiek fauna representing 26\% of specimens (Briggs et al. 2015). They are morphologically variable, but are characterized by a roughly cylindrical shape and a surface texture featuring concentric wrinkles or bands. Liu et al. (2006) argued that, whereas some of these structures may represent coprolites, others show a regularity of external morphology and internal structure that makes the coprolite interpretation unlikely. Subsequent authors have referred to the Winneshiek vermiform structures as bromalites (Briggs et al. 2015; Liu et al. 2017), which includes coprolites and cololites - the mineralized contents of digestive organs (Hunt 1992). Here we report a systematic investigation of these structures to determine their formation, mode of preservation, and likely makers.

We examined a set of bromalites from the Winneshiek Shale, analyzed the details of their external morphology, and used these observations to develop a list of morphological features occurring across multiple specimens. We utilized light and scanning electron microscopy to investigate polished slabs and thin sections of specimens in order to characterize their internal structure and mineralogical composition. The morphological and compositional features were then compared with those of other bromalite assemblages and modern fecal pellet assemblages described in the literature.

\section{GEOLOGIC SETTING AND BACKGROUND}

\section{The Winneshiek Shale}

The Middle Ordovician Winneshiek Shale was first recognized within cores and well cuttings in the early 2000s, which revealed a green to gray shale underlying the Tonti Member of the St. Peters Formation (Liu et al. 2017). The occurrence of this unit is restricted to a circular area with a diameter of approximately $5.6 \mathrm{~km}$ around the city of Decorah, Iowa (McKay et al. 2011; Witzke et al. 2011). The shale unit is underlain by a previously unrecognized breccia, a unit containing clasts and sediments derived from underlying Cambrian and Lower Ordovician strata. Stratigraphic deformation and brecciation are also evident at the edge of the circular basin. Petrographic examination of quartz grains from core and well cuttings of the breccia unit has documented the presence of shock- 


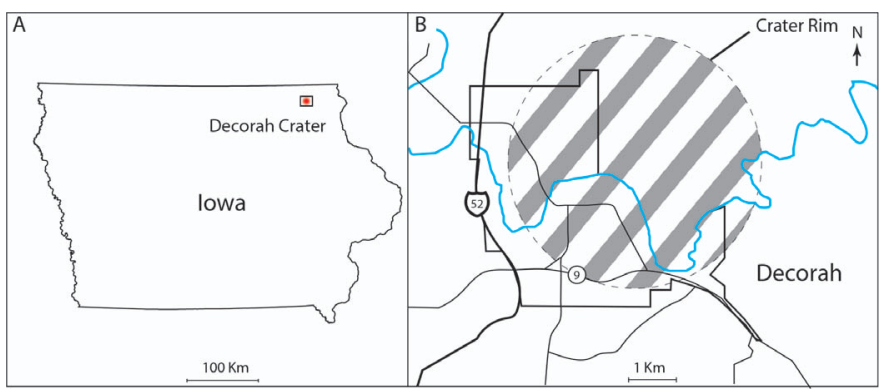

FIG. 1.-Locality maps. A) Iowa map showing the location of the Decorah impact structure. B) Map of Decorah, Iowa, showing the outline of the impact structure.

deformation features diagnostic of meteorite impact origin. Taken together, these individual pieces of evidence suggested the existence of a previously unrecognized meteorite impact structure located beneath the city of Decorah (Fig. 1) (Liu et al. 2009; McKay et al. 2010, 2011). Aerial electromagnetic and gravity surveys operated by the U.S. Geological Survey clarified the spatial extent and geometry of this structure, which was named the Decorah impact structure (Kass et al. 2013a, 2013b). The age of the Winneshiek Shale deposited within the crater is constrained to be Middle Ordovician (Darriwilian, or Whiterockian in regional terminology) by both the surrounding stratigraphic context and, especially, by conodonts in the Winneshiek Shale (Liu et al. 2017). The Decorah impact structure is one of several Ordovician impact structures that have been discovered in recent years. These structures, along with elevated abundances of impact-related osmium isotopes, have been used to argue for an increased frequency of asteroid impacts related to an L-chondrite parent-body breakup event (Korochantseva et al. 2007; Schmitz et al. 2008).

The depositional setting of the Winneshiek Shale within the impact crater differed significantly from that of the underlying brecciated rocks (McKay et al. 2010, 2011). The Winneshiek Shale is organic rich, with total organic carbon contents up to $1.5 \%$ based on Rock-Eval analysis. Pyrite framboids are abundant. The green-gray shale is laminated with no evidence of bioturbation. These observations suggest that the paleoenvironment that formed in the impact crater was that of a restricted basin with dysoxic or anoxic bottom waters (Liu et al. 2009; McKay et al. 2011).

\section{Winneshiek Biota and Exceptional Preservation}

The Winneshiek biota comprises a suite of taxa that supports its interpretation as an assemblage hosted in a restricted embayment or estuary with low dissolved oxygen levels, marginal to the main Whiterockian seaway (Witzke et al. 2011). The biota is dominated by conodonts and arthropods, with abundant bromalites as well as inarticulate brachiopods, algae, and possible fishes. As noted above, common constituents of normal marine communities, such as articulate brachiopods and trilobites, are absent. The arthropods include the phyllocarid Ceratiocaris winneshiekensis, the oldest known representative of the Ceratiocarididae (Briggs et al. 2015), the oldest described eurypterid (Lamsdell et al. 2015b), a basal euchelicerate arthropod (Lamsdell et al. 2015a), and several species of ostracods (Briggs et al. 2015). Additionally, organic-walled microfossils have been extracted from the Winneshiek Shale using palynological techniques (Nowak et al. 2017). Conodonts occur as new complete giant apparatuses as well as individual elements (Liu et al. 2017). Possible jawless fishes are represented by articulated head shields (Liu et al. 2006). Linguloid brachiopods as well as a single gastropod specimen have also been found. The character of the Winneshiek biota differs from other broadly regional Ordovician shelly faunas of apparently restricted marginal marine paleoenvironments, including the Upper Ordovician Lagerstätten at McBeth Point, Williams Lake, and Airport Cove in Manitoba, Canada (Young et al. 2007, 2013) and the Stonington Peninsula in Michigan (Lamsdell et al. 2017). No fossils similar to the Winneshiek bromalites have been described from these sites.

\section{METHODS}

Following the discovery of the Winneshiek Shale in cores and well cuttings, an artificial section was created along a small exposure by the Upper Iowa River using a backhoe. This area of the river is normally submerged and was cordoned off for excavation in the summer of 2010. More than 5,000 specimens of arthropods, conodonts, bromalites, and other components of the Winneshiek biota were collected. Most of the bromalites used in this study were collected during the 2010 excavation, although some specimens were obtained from slabs that were washed out of the river bed during flooding. All specimens examined in this study are held at the Paleontology Repository, Department of Earth and Environmental Sciences, University of Iowa (catalog numbers with the prefix SUI).

A combination of transmitted light, reflected light, scanning electron microscopy (SEM), and electron microprobe was used to examine the internal and surficial microstructures of a morphologically diverse set of bromalites that were naturally exposed or thin-sectioned. A total of 56 specimens was observed via reflected light microscopy to document their external morphologies. Thirteen specimens were cut and polished for SEM examination, and five of them were prepared for standard $30-\mu \mathrm{m}$ petrographic thin sections. One of the thin sections intersected an unexposed bromalite, so that a total of 14 sectioned specimens were examined by SEM. Thin sections were studied using an Olympus BX-51 transmitted light microscope. Compositional data and elemental maps were obtained from polished slabs and thin sections on a Hitachi TM3000 table top SEM with a Bruker XFlash energy dispersive X-ray spectroscopy (EDS) system using an accelerating voltage of $15 \mathrm{kV}$ and a working distance of $12 \mathrm{~mm}$, and also on a FEI Quanta 600F environmental SEM using accelerating voltages of 5-20 kV and a working distance of 5-13 $\mathrm{mm}$. The majority of images were taken in backscattered electron (BSE) mode as this revealed more subsurface structures of interest (Muscente and Xiao 2015; Tang et al. 2017), but in some cases secondary electron (SE) imaging was used. BSE imaging generates grayscale images in which the contrast reflects composition and packing density (Schiffbauer et al. 2012). SE imaging, in contrast, detects secondary electrons, providing image contrast that mainly reflects topography (Muscente and Xiao 2015). We also analyzed the composition of two bromalites in thin section using a Cameca SX-50 electron microprobe with a Bruker SDD energy dispersive spectrometer system. Electron microprobe analysis was conducted using an accelerating voltage of $15 \mathrm{kV}$.

\section{RESULTS}

\section{Composition}

Most bromalites from the Winneshiek are more or less cylindrical in shape (Figs. 2-4). SEM elemental mapping of longitudinal thin sections indicated that specimens are composed of calcium phosphate (Fig. 2). Microprobe analysis confirmed that calcium and phosphorus are abundant, and that fluorine and chlorine are present in appreciable amounts (Table 1), indicating that the specimens are likely composed of carbonate fluorapatite. These results suggest that phosphatization was the primary preservation pathway. Some specimens exhibit significant amounts of pyrite (Fig. 3J, $3 \mathrm{~K}$ ) and sphalerite (Fig. 3N). A small number of specimens are extensively pyritized (Fig. 3J), in some cases with a phosphatic outer layer (Fig. 3K). The specimens examined in thick or thin section only revealed local secondary pyrite (bright spots in Fig. 2C, 2D). However, we did not section 

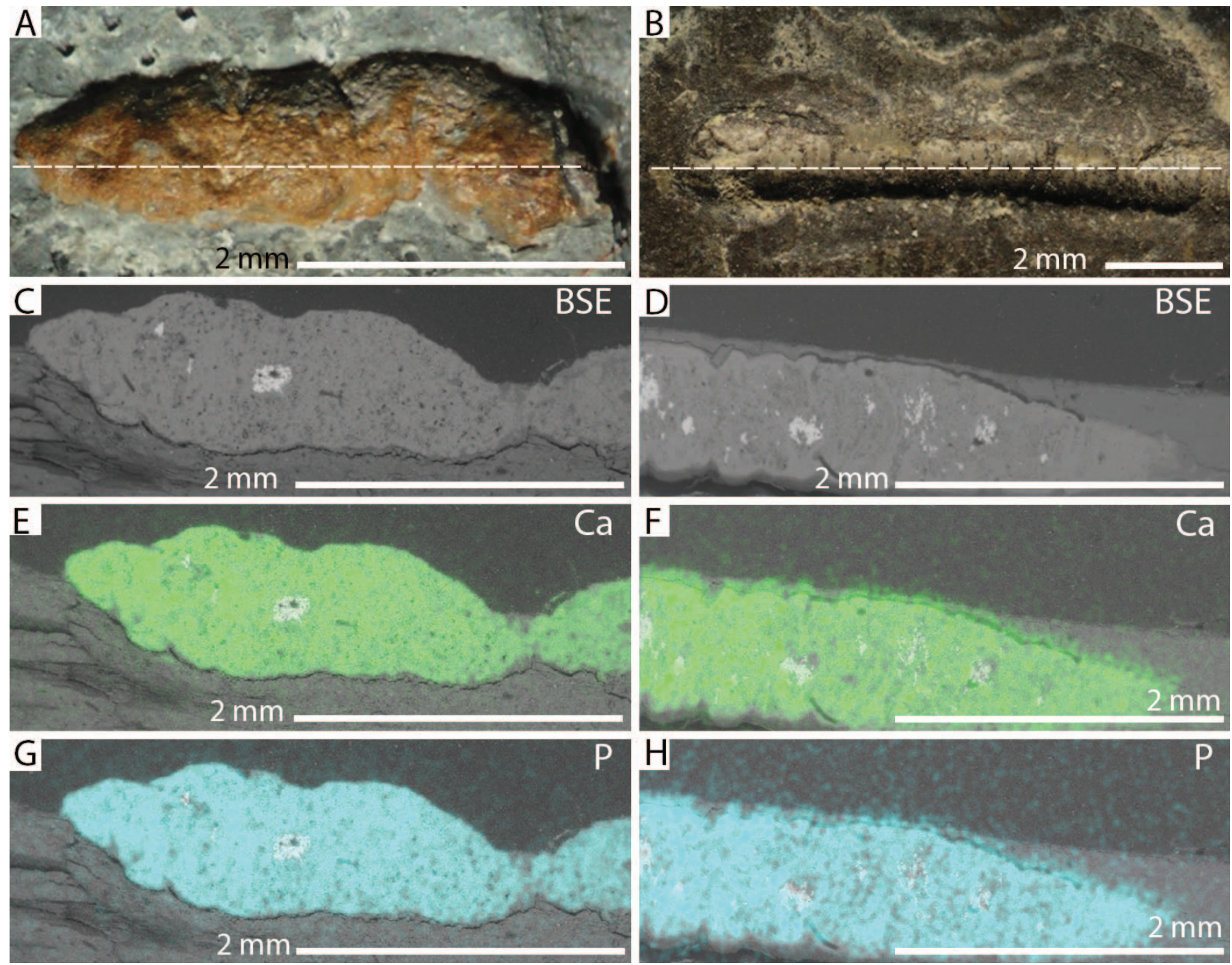

FIG. 2.-Longitudinally sectioned vermiform structures. A, B) Reflected light images of SUI 145137 and SUI 145138, respectively. Dashed lines (A, B) mark approximate locations of sectional views shown in (C, E, G) and (D, F, H), respectively. C, D) BSE images; white color, pyrite. E-H) EDS elemental maps superimposed on BSE images.

any of the pervasively pyritized specimens, and therefore cannot exclude a more complex taphonomic scenario involving pyritization in those cases (e.g., Schiffbauer et al. 2014; Muscente et al. 2017). Calcite is also present in some specimens as euhedral rhombs and is inferred to represent a later diagenetic product. A subset of specimens was not phosphatized, but preserved as carbonaceous compressions (Fig. 3F). A small number of specimens are partially phosphatized and partially preserved as carbonaceous compressions (Fig. 3L). These specimens provide a link between fully carbonaceous specimens and three-dimensionally phosphatized bromalites. An additional subset of vermiform specimens appears to represent subcylindrical structures filled with quartz sand; they locally appear as patches of quartz sand in the shale (Fig. $4 \mathrm{~K}-4 \mathrm{~N}$ ).

\section{External Morphology}

The most obvious morphological division among Winneshiek Shale vermiform fossils is between those preserved as carbonaceous compressions and those preserved three-dimensionally. While some ribbonshaped carbonaceous compressions may also be bromalites, the main focus of this study is the three-dimensional forms, particularly the phosphatized specimens. The three-dimensionally preserved bromalites exhibit variations in shape, size, and surface texture (Fig. 4). A few specimens exhibit a distinct ovoid morphology that tapers at one end to a neck (Fig. 3A), and a small number of specimens are characterized by irregularly folded and coiled segments (Fig. 3C-3E). However, most three-dimensionally preserved Winneshiek bromalites are either elongate cylindrical rod-like structures, or somewhat compressed subcylindrical structures.

We recognized five morphological groups or end-members among the commonly occurring morphologies of three-dimensionally preserved Winneshiek bromalites based on shape and surface texture: (1) densely corrugated and rod-like (Fig. 4A-4C); (2) densely corrugated and compressed due to compaction prior to mineralization (Fig. 4D, 4E); (3) unsculpted and compressed (Fig. 4F, 4G); (4) unsculpted rodlike (Fig. 4H-4J); and (5) patches of quartz sand, which may represent coprolites of animals that ingested sand (Fig. 4K-4N). Some specimens exhibit more than one of these end-members at different sections along their longitudinal axis (Fig. 5), and others show intermediate morphologies, suggesting that the variation may be taphonomic in origin due to compaction, deformation, or decay. 

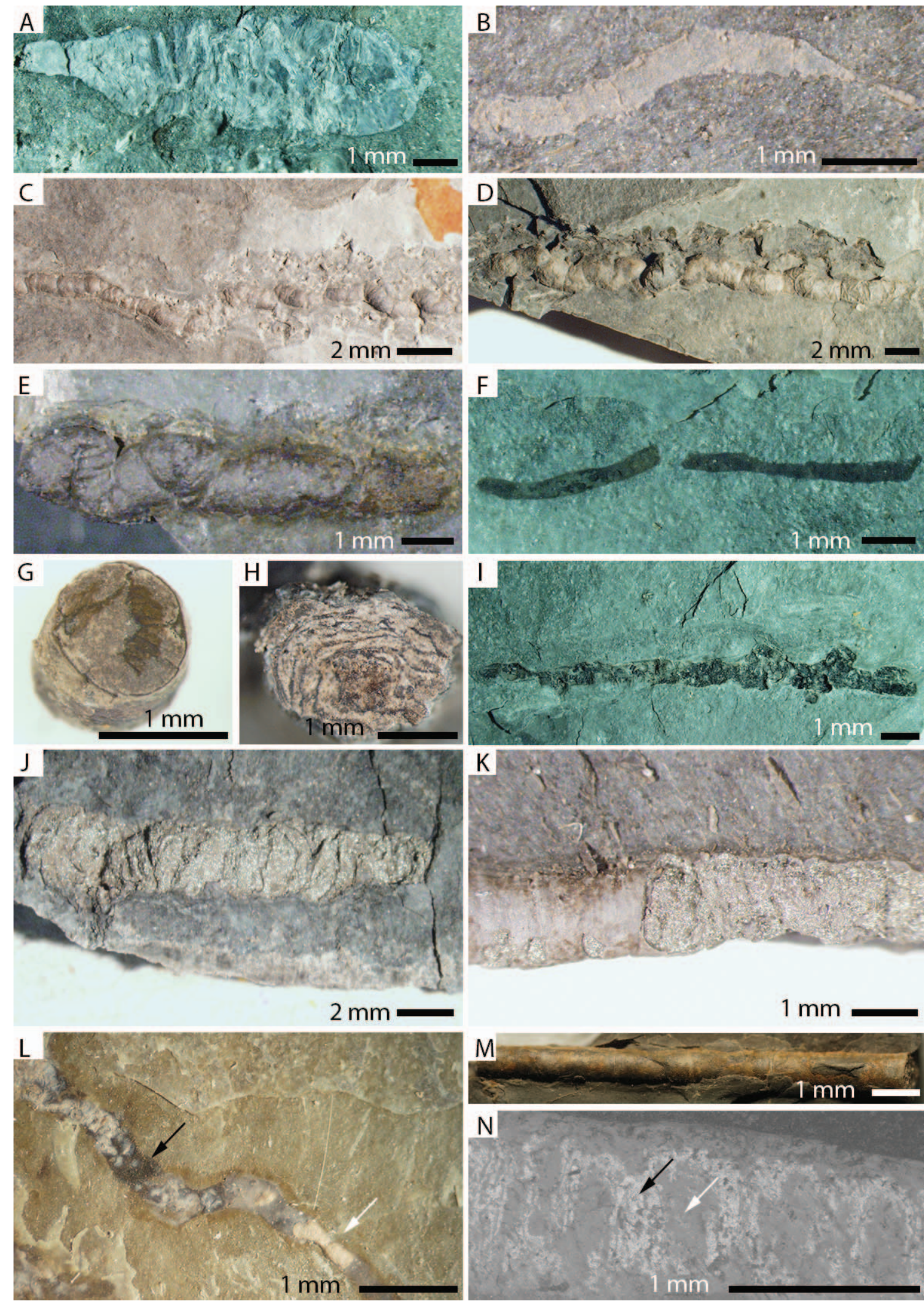

Fig. 3.- Reflected light images (A-M) and BSE image (N) of bromalites. A) Specimen exhibiting a tapered neck feature: SUI 145144 (WL61). B) Possible additional specimen with a tapered neck structure: SUI 145145 (WS18-264). C, D) Specimens exhibiting a coiled morphology: SUI 145146 (WS11-434) and 145147 (WL140), respectively. E) Specimen with irregularly folded structures: SUI 145148 (WS16-541). F) Carbonaceous compression specimen: SUI 145149 (WL55). G, H) Specimens in transverse cross-section: SUI 145150 (WL90) and SUI 145151 (WS10-242), respectively. I) Specimen showing apparent branching structure that could be a taphonomic 

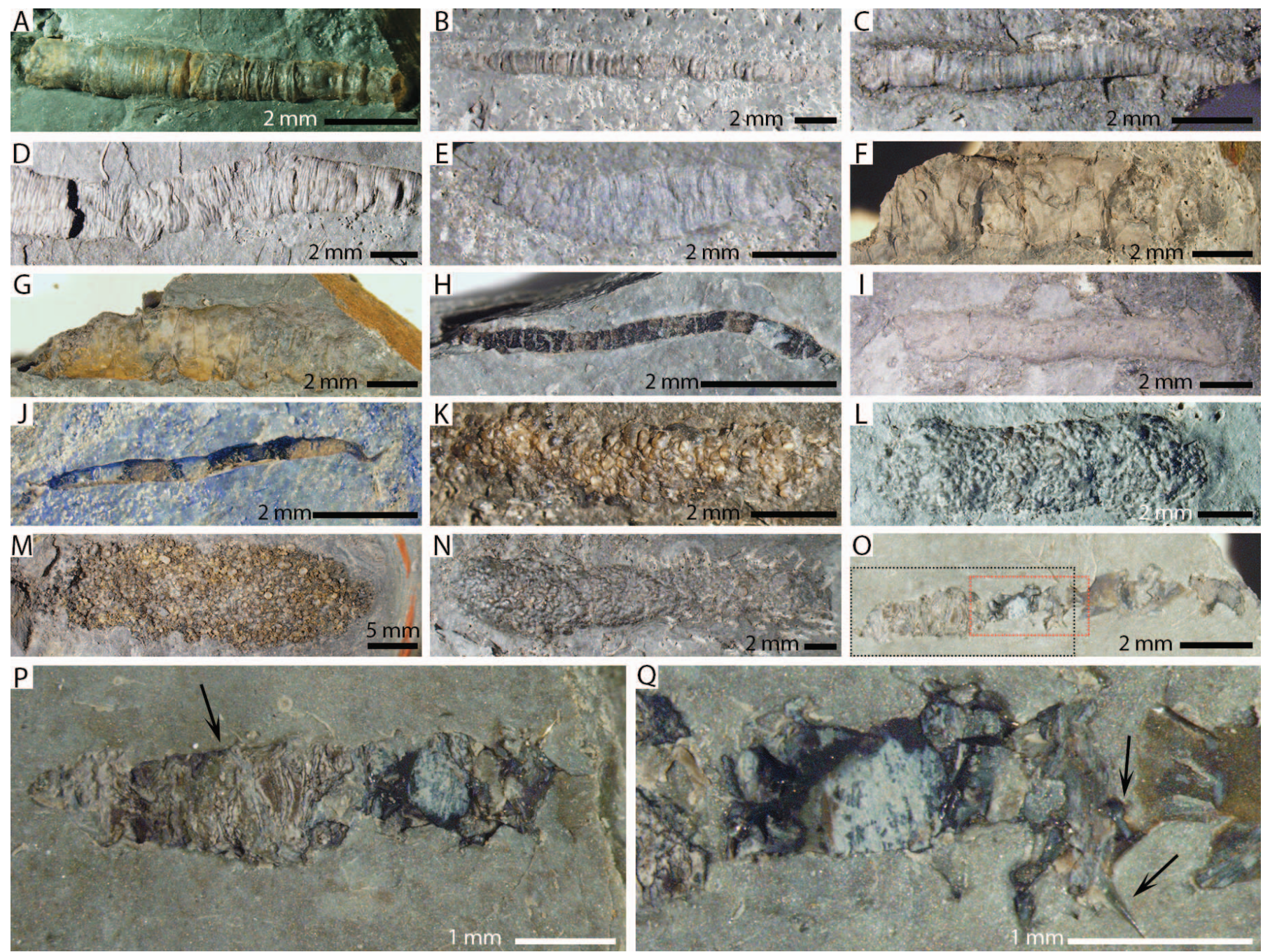

FIG. 4.-Reflected light images of bromalites. A-C) Densely corrugated rod-like specimens: SUI 145155 (WL8), SUI 145156 (WS14-417), SUI 145157 (WS14-559), respectively. D, E) Densely corrugated and compressed specimens: SUI 145158 (WS14-549) and SUI 145159 (WS14-519), respectively. F, G) Unsculpted and compressed specimens: SUI 145160 (WL115) and SUI 145161 (WL119), respectively. H-J) Unsculpted rod-like specimens: SUI 145162 (WS9-148), SUI 145163 (WS14-548), and SUI 145164 (WL31), respectively. K-N) Specimens defined by concentration of quartz sand: SUI 145165 (WL99), SUI 145166 (WL182), SUI 145167 (WS10-200), and SUI 14568 (WS14-229), respectively. O-Q) Specimen exhibiting morphological variation along its length and containing conodont elements: SUI 145169 (WL95). Black and red rectangles in $(\mathrm{O})$ mark magnified views shown in (P, counterpart) and $(\mathrm{Q})$, respectively. Part of the specimen is somewhat three-dimensionally preserved and shows transverse wrinkles or striations (arrow in P) characteristic of phosphatized specimens analyzed in this study, and part of the specimen is preserved as carbonaceous compression with conodont inclusions (arrows in Q).

Variation in bromalites may also be related to differences in the gut contents at the time of death. Table 2 lists specimens included in this study and their group assignment.

Specimens that fall within group 1, densely corrugated and rod-like (Fig. 4A-4C), display an external morphology consisting of transverse bands or corrugations. The density of these bands varies from specimen to specimen: some specimens are continuously banded throughout their length while others exhibit discrete bands separated from one another by a smooth region. Specimens in group 1 are elongate in shape and subcylindrical in cross-section. The seven representatives are $1.1 \mathrm{~mm}$ in mean width.

Group 2, densely corrugated and compressed, contains 10 specimens (e.g., Fig. 4D, 4E). They represent a more compressed version of group 1. Specimens in group 2 also exhibit transverse corrugations, and some have a greater density of surface corrugations than in their group 1 counterparts. The mean width of specimens in this group is $1.7 \mathrm{~mm}$.

Group 3, unsculpted and compressed, consists of specimens that are somewhat compressed and lack any of the prominent transverse

artifact: SUI 145152 (WL53). J, K) Partially pyritized bromalites: SUI 145153 (WS13-503) and SUI 145154 (WS14-104), respectively. L) Bromalite that is partially phosphatized (white arrow) and partially preserved as a carbonaceous compression (black arrow): SUI 145173. M) Rod-shaped bromalite: SUI 145140. N) BSE image of a partial longitudinal cross-section of (M), showing transverse 'segmentation' structures. The specimen is replicated by phosphate (darker color; white arrow) and sphalerite (brighter color; black arrow). The identification of sphalerite has been confirmed by EDS data. 
TABLE 1.- Results of microprobe analysis of Winneshiek bromalites and shale matrix. The top and bottom specimens are illustrated in Figure 9A.

\begin{tabular}{|c|c|c|c|c|c|c|c|c|c|}
\hline Measurement \# & $\mathrm{P}_{2} \mathrm{O}_{5}$ & $\mathrm{Al}_{2} \mathrm{O}_{3}$ & $\mathrm{MgO}$ & $\mathrm{CaO}$ & $\mathrm{MnO}$ & $\mathrm{FeO}$ & $\mathrm{F}$ & $\mathrm{Cl}$ & Measurement target \\
\hline 1 & 29.80 & 0.01 & 0.00 & 43.10 & 0.30 & 0.37 & 2.40 & 0.20 & Top vermiform specimen \\
\hline 2 & 27.35 & 0.04 & 0.00 & 38.90 & 0.29 & 0.23 & 2.46 & 0.23 & Top vermiform specimen \\
\hline 3 & 29.58 & 0.07 & 0.00 & 42.30 & 0.29 & 0.36 & 4.21 & 0.21 & Top vermiform specimen \\
\hline 4 & 31.29 & 0.24 & 0.00 & 44.49 & 0.33 & 0.47 & 2.67 & 0.15 & Top vermiform specimen \\
\hline 5 & 20.21 & 0.04 & 0.00 & 28.54 & 0.20 & 0.32 & 1.36 & 0.44 & Top vermiform specimen \\
\hline 6 & 27.91 & 0.02 & 0.00 & 41.07 & 0.21 & 0.27 & 2.37 & 0.23 & Top vermiform specimen \\
\hline 7 & 30.03 & 0.03 & 0.00 & 42.25 & 0.30 & 0.41 & 1.96 & 0.20 & Top vermiform specimen \\
\hline 8 & 24.34 & 0.03 & 0.00 & 35.04 & 0.18 & 0.32 & 2.20 & 0.32 & Top vermiform specimen \\
\hline 9 & 0.35 & 25.28 & 1.87 & 0.08 & 0.00 & 5.87 & 0.45 & 0.01 & Winneshiek Shale \\
\hline 10 & 0.24 & 25.16 & 1.66 & 0.21 & 0.00 & 5.13 & 0.04 & 0.01 & Winneshiek Shale \\
\hline 11 & 0.25 & 22.89 & 1.44 & 0.12 & 0.03 & 3.82 & 0.27 & 0.02 & Winneshiek Shale \\
\hline 12 & 0.25 & 23.28 & 1.63 & 2.20 & 0.01 & 4.16 & 0.17 & 0.01 & Winneshiek Shale \\
\hline 13 & 0.13 & 20.13 & 1.27 & 2.27 & 0.02 & 11.62 & 0.22 & 0.01 & Winneshiek Shale \\
\hline 14 & 0.13 & 20.31 & 1.29 & 2.12 & 0.05 & 7.41 & 0.23 & 0.01 & Winneshiek Shale \\
\hline 15 & 0.19 & 18.14 & 1.18 & 0.99 & 0.00 & 3.38 & 0.37 & 0.00 & Winneshiek Shale \\
\hline 16 & 0.15 & 21.04 & 1.45 & 0.44 & 0.01 & 3.36 & 0.08 & 0.01 & Winneshiek Shale \\
\hline 17 & 0.19 & 22.35 & 1.53 & 0.79 & 0.00 & 4.33 & 0.13 & 0.00 & Winneshiek Shale \\
\hline 18 & 0.09 & 19.52 & 1.14 & 0.43 & 0.00 & 3.62 & 0.13 & 0.01 & Winneshiek Shale \\
\hline 19 & 0.15 & 21.18 & 1.52 & 0.32 & 0.00 & 2.81 & 0.19 & 0.00 & Winneshiek Shale \\
\hline 20 & 0.16 & 19.53 & 1.43 & 0.31 & 0.01 & 1.95 & 0.08 & 0.03 & Winneshiek Shale \\
\hline 21 & 0.10 & 19.99 & 1.41 & 0.21 & 0.00 & 1.33 & 0.15 & 0.02 & Winneshiek Shale \\
\hline 22 & 0.04 & 0.01 & 0.00 & 0.03 & 0.00 & 0.05 & 0.11 & 0.01 & Winneshiek Shale \\
\hline 23 & 0.04 & 11.26 & 0.70 & 1.09 & 0.00 & 1.40 & 0.00 & 0.02 & Winneshiek Shale \\
\hline 24 & 0.05 & 13.22 & 1.06 & 0.93 & 0.00 & 2.73 & 0.02 & 0.01 & Winneshiek Shale \\
\hline 25 & 0.10 & 12.56 & 0.32 & 1.31 & 0.01 & 3.18 & 0.00 & 0.01 & Winneshiek Shale \\
\hline 26 & 0.08 & 20.57 & 1.55 & 0.14 & 0.02 & 2.25 & 0.29 & 0.00 & Winneshiek Shale \\
\hline 27 & 0.12 & 24.33 & 1.69 & 0.12 & 0.01 & 4.84 & 0.51 & 0.02 & Winneshiek Shale \\
\hline 28 & 0.07 & 19.66 & 1.31 & 0.16 & 0.02 & 3.28 & 0.23 & 0.01 & Winneshiek Shale \\
\hline 29 & 0.03 & 20.05 & 0.81 & 0.14 & 0.00 & 2.84 & 0.00 & 0.02 & Winneshiek Shale \\
\hline 30 & 0.06 & 15.45 & 1.01 & 0.69 & 0.00 & 2.49 & 0.06 & 0.01 & Winneshiek Shale \\
\hline 31 & 0.15 & 25.15 & 1.87 & 0.10 & 0.01 & 5.05 & 0.20 & 0.01 & Winneshiek Shale \\
\hline 32 & 0.09 & 23.90 & 1.78 & 0.12 & 0.03 & 3.65 & 0.00 & 0.02 & Winneshiek Shale \\
\hline 33 & 0.09 & 25.61 & 1.88 & 0.10 & 0.03 & 4.45 & 0.06 & 0.01 & Winneshiek Shale \\
\hline 34 & 0.14 & 25.55 & 1.85 & 0.12 & 0.00 & 4.45 & 0.22 & 0.01 & Winneshiek Shale \\
\hline 35 & 0.16 & 14.53 & 1.07 & 0.12 & 0.00 & 3.82 & 0.41 & 0.01 & Winneshiek Shale \\
\hline 36 & 0.29 & 23.91 & 1.69 & 0.10 & 0.01 & 7.62 & 0.23 & 0.01 & Winneshiek Shale \\
\hline 37 & 0.21 & 24.62 & 1.79 & 0.10 & 0.02 & 7.32 & 0.16 & 0.03 & Winneshiek Shale \\
\hline 38 & 0.22 & 24.44 & 1.69 & 0.06 & 0.00 & 7.26 & 0.00 & 0.02 & Winneshiek Shale \\
\hline 39 & 0.14 & 21.67 & 1.55 & 0.07 & 0.02 & 5.45 & 0.44 & 0.02 & Winneshiek Shale \\
\hline 40 & 0.34 & 25.12 & 1.78 & 0.12 & 0.01 & 7.40 & 0.18 & 0.02 & Winneshiek Shale \\
\hline 41 & 27.14 & 0.12 & 0.00 & 38.92 & 0.21 & 1.61 & 2.84 & 0.16 & Bottom vermiform specimen \\
\hline 42 & 25.11 & 0.15 & 0.00 & 35.45 & 0.17 & 0.34 & 1.28 & 0.27 & Bottom vermiform specimen \\
\hline 43 & 19.24 & 2.64 & 0.00 & 27.71 & 0.00 & 0.39 & 1.77 & 0.30 & Bottom vermiform specimen \\
\hline 44 & 22.89 & 0.16 & 0.00 & 32.90 & 0.15 & 1.16 & 2.74 & 0.26 & Bottom vermiform specimen \\
\hline
\end{tabular}
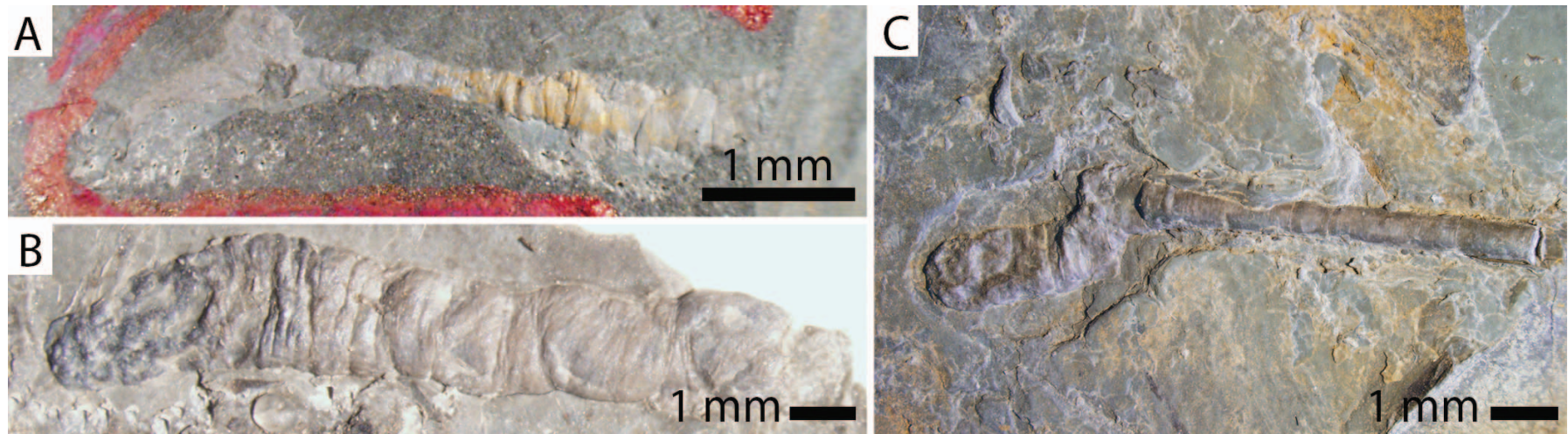

FIG. 5.-Reflected light images of bromalites exhibiting evidence of deformation or liquefaction. A) SUI 145170 (WS14-310). B) SUI 145171 (WS11-472). C) SUI 145172 (WL28). 
TABLE 2.- - List of specimens representing end-member morphological groups and their measurements.

\begin{tabular}{|c|c|c|c|c|c|}
\hline Specimen \# & SUI \# & Figure \# & Morphological group & Length (mm) & Width $(\mathrm{mm})$ \\
\hline WL8 & 145155 & Figure $4 \mathrm{~A}$ & 1. Corrugated rod & 8.1 & 1.0 \\
\hline WL95 & 145169 & Figure $4 \mathrm{O}-4 \mathrm{Q}$ & 1. Corrugated rod & 10.7 & 1.4 \\
\hline WS14-368 & & Not illustrated & 1. Corrugated rod & 15.3 & 0.5 \\
\hline WS14-417 & 145156 & Figure 4B & 1. Corrugated rod & 18.2 & 1.3 \\
\hline WS14-425 & & Not illustrated & 1. Corrugated rod & 21.5 & 1.0 \\
\hline WS14-559 & 145157 & Figure $4 \mathrm{C}$ & 1. Corrugated rod & 9.7 & 0.8 \\
\hline WS14-104 & 145154 & Figure $3 \mathrm{~K}$ & 1. Corrugated rod & 29.0 & 1.7 \\
\hline WS10-199 & & Not illustrated & 2. Corrugated compressed & 25.9 & 2.7 \\
\hline WS14-519 & 145159 & Figure 4E & 2. Corrugated compressed & 7.2 & 1.7 \\
\hline WL44 & & Not illustrated & 2. Corrugated compressed & 16.5 & 1.0 \\
\hline WS14-549 & 145158 & Figure 4D & 2. Corrugated compressed & 25.1 & 2.5 \\
\hline WS14-558 & & Not illustrated & 2. Corrugated compressed & 9.3 & 1.6 \\
\hline WS11-472 & 145171 & Figure 5B & 2. Corrugated compressed & 12.1 & 1.8 \\
\hline WS13-183 & & Not illustrated & 2. Corrugated compressed & 5.9 & 0.4 \\
\hline WL18 & & Not illustrated & 3. Unsculpted rod & 16.4 & 0.9 \\
\hline WL28 & 145172 & Figure $5 \mathrm{C}$ & 3. Unsculpted rod & 15.3 & 1.4 \\
\hline WL31 & 145164 & Figure 4J & 3. Unsculpted rod & 15.3 & 0.7 \\
\hline WL68 & & Not illustrated & 3. Unsculpted rod & 4.9 & 0.6 \\
\hline WL114 & & Not illustrated & 3. Unsculpted rod & 10.1 & 0.9 \\
\hline WL120 & & Not illustrated & 3. Unsculpted rod & 7.6 & 0.9 \\
\hline WL140 & 145147 & Figure 3D & 3. Unsculpted rod & 29.8 & 1.9 \\
\hline WL221 & & Not illustrated & 3. Unsculpted rod & 6.8 & 0.4 \\
\hline WS9-148 & 145162 & Figure $4 \mathrm{H}$ & 3. Unsculpted rod & 5.7 & 0.3 \\
\hline WS11-453 & & Not illustrated & 3. Unsculpted rod & 27.1 & 2.3 \\
\hline WS14-416 & & Not illustrated & 3. Unsculpted rod & 8.7 & 0.7 \\
\hline WS14-451 & & Not illustrated & 3. Unsculpted rod & 9.8 & 0.3 \\
\hline WS14-548 & 145163 & Figure 4I & 3. Unsculpted rod & 11.6 & 1.7 \\
\hline WS16-541 & 145148 & Figure $3 \mathrm{E}$ & 3. Unsculpted rod & 8.3 & 0.6 \\
\hline WL71 & & Not illustrated & 4. Unsculpted compressed & & 0.3 \\
\hline WL115 & 145160 & Figure 4F & 4. Unsculpted compressed & 12.1 & 3.2 \\
\hline WL119 & 145161 & Figure $4 \mathrm{G}$ & 4. Unsculpted compressed & 15.2 & 1.8 \\
\hline WS12-243 & & Not illustrated & 4. Unsculpted compressed & 14.1 & 2.2 \\
\hline WS12-465 & & Not illustrated & 4. Unsculpted compressed & 3.5 & 0.6 \\
\hline WS12-528 & & Not illustrated & 4. Unsculpted compressed & 10.8 & 0.6 \\
\hline WS14-365 & & Not illustrated & 4. Unsculpted compressed & 17.3 & 2.8 \\
\hline WS17-63 & & Not illustrated & 4. Unsculpted compressed & 14.7 & 0.5 \\
\hline WL99 & 145165 & Figure $4 \mathrm{~K}$ & 5. Granular & 8.2 & 1.7 \\
\hline WL104 & & Not illustrated & 5. Granular & 5.3 & 2.0 \\
\hline WL182 & 145166 & Figure 4L & 5. Granular & 11.3 & 3.2 \\
\hline WL187 & & Not illustrated & 5. Granular & 82.4 & 5.0 \\
\hline WL201 & & Not illustrated & 5. Granular & 9.3 & 0.9 \\
\hline WS10-200 & 145167 & Figure 4M & 5. Granular & 29.5 & 9.7 \\
\hline WS12-498 & & Not illustrated & 5. Granular & 13.1 & 1.1 \\
\hline WS12-508 & & Not illustrated & 5. Granular & 12.0 & 1.0 \\
\hline WS14-229 & 145168 & Figure $4 \mathrm{~N}$ & 5. Granular & 23.0 & 4.1 \\
\hline WS14-556 & & Not illustrated & 5. Granular & 12.2 & 1.4 \\
\hline WS14-156 & & Not illustrated & 5. Granular & 5.4 & 1.6 \\
\hline
\end{tabular}

corrugations observed in the first two groups, instead exhibiting a relatively smooth surface with subtle and sparse transverse lineations (Fig. 4F, 4G). The eight specimens are $1.5 \mathrm{~mm}$ in mean width. There are specimens intermediate between this group and groups 1 and 2.

Group 4, unsculpted rod-like, lacks any transverse corrugations observed in the first two groups, instead exhibiting an unsculpted surface texture (Fig. 4H-4J). The fourteen specimens have a mean width of 0.96 $\mathrm{mm}$. Several specimens appear to be intermediate between this group and group 1, densely corrugated rod-like, exhibiting subtle surface sculpture separated by homogenous regions. A single specimen appears corrugated over a portion of its length and unsculpted over the remainder.

Group 5, patches of quartz sand, is represented by eleven specimens (Fig. $4 \mathrm{~K}-4 \mathrm{~N}$ ) that average $2.9 \mathrm{~mm}$ in width. The specimens have a granular or pustular appearance. There are no specimens in our collection intermediate between this group and groups 1-4. Thus, group 5 represents a discrete morphological category among Winneshiek vermiform fossils and it is not a focus of this study.

\section{Internal Structure of Phosphatized Bromalites}

The three-dimensionally phosphatized bromalites vary in their internal structure as revealed in thin section. They commonly show densely packed microspherules 2-5 microns in diameter (Fig. 6). We did not observe any systematic covariation between external morphology and internal structure. Indeed, the majority of sectioned vermiform structures exhibit a similar internal structure (see below) in spite of significant differences in external morphology. Microspherules are present throughout the entire volume of many specimens (Figs. 6-9). Many are translucent when viewed in 

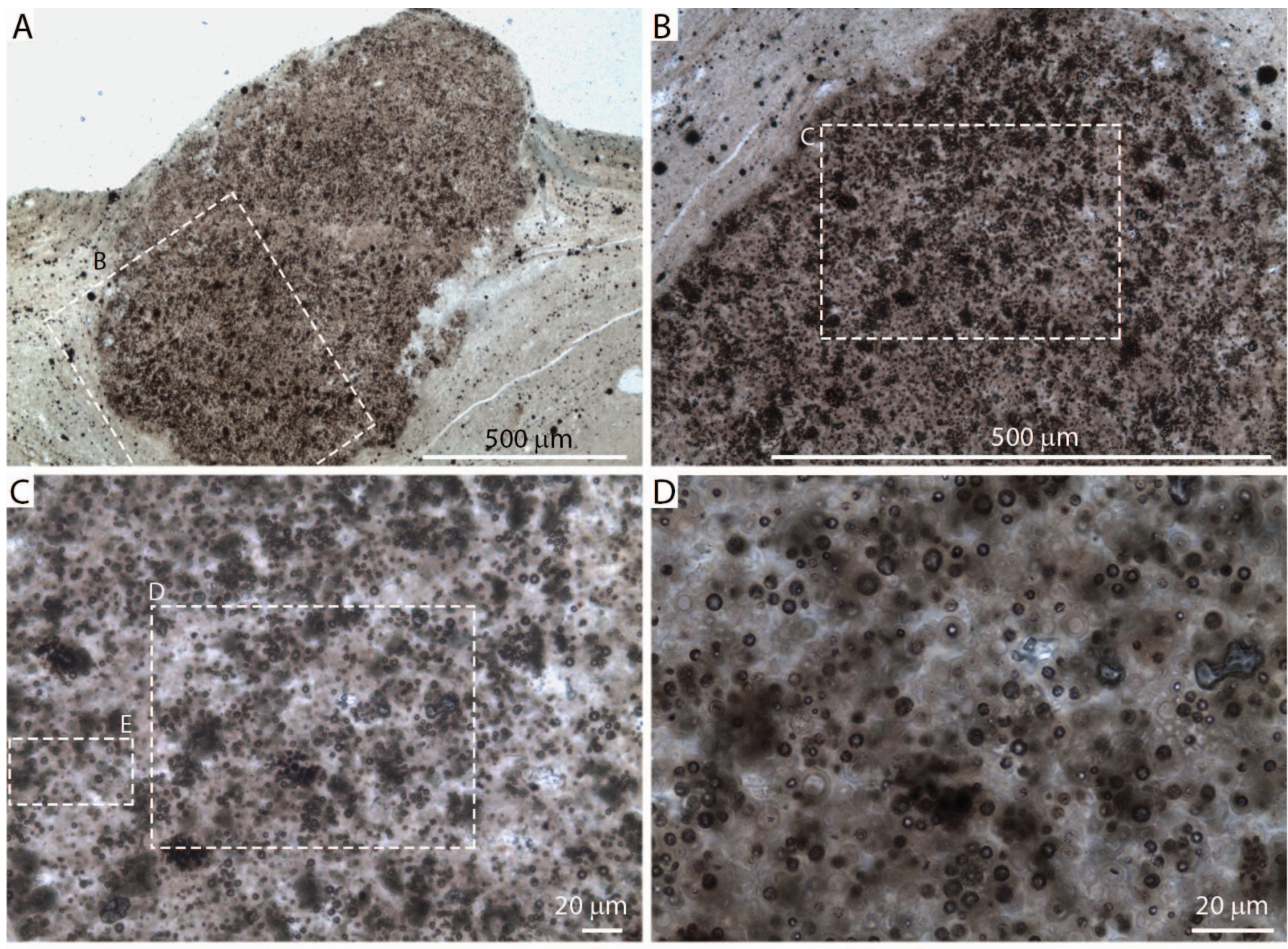

E

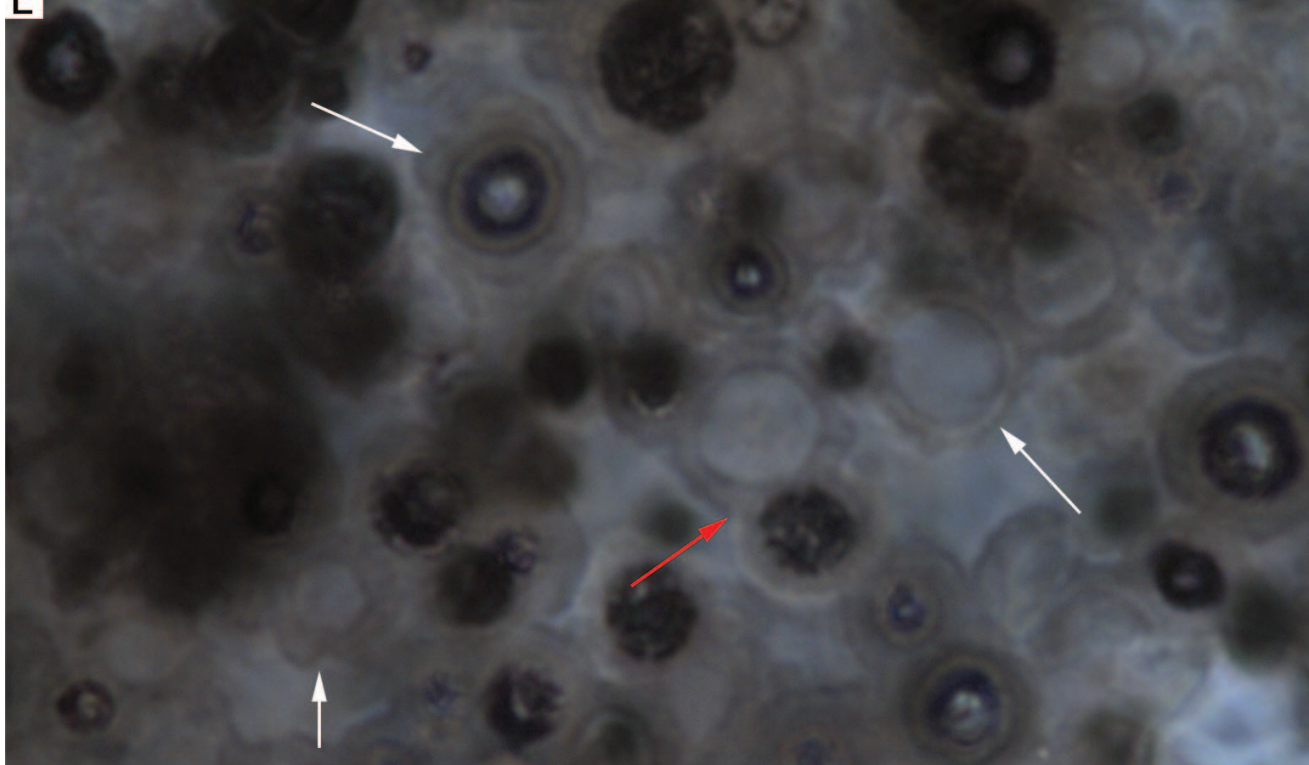



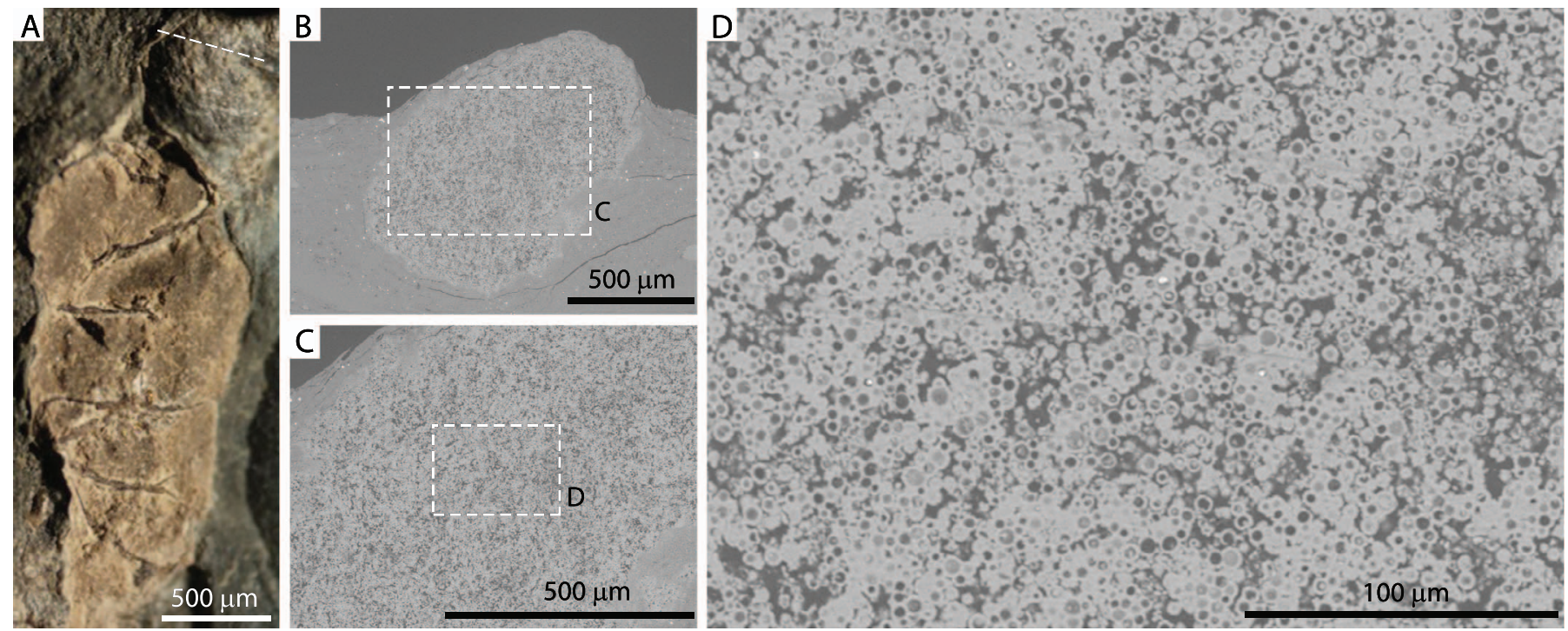

FIG. 7.- Specimen with densely packed microspherules, SUI 145141. A) Reflected light image. White dashed line indicates approximately where the specimen was cut for thin section preparation. B-D) BSE images. Rectangles in (B) and (C) mark areas magnified in (C) and (D), respectively. The specimen is also illustrated in Figure 6 and Figure 9A (top specimen).

transmitted light microscopy, varying somewhat in color but generally appearing yellow-brown or golden. But a subset of microspherules differs in being dark in color to opaque (Fig. 6C-E). Other phosphatic specimens exhibit a less homogenous internal structure. For example, some show distinct concentric bands in transverse cross section (Fig. 3H), one exhibits a distinct transverse "segmentation" in longitudinal cross section (Fig. $3 \mathrm{~N}$ ), and another specimen contains conodont elements (Fig. 4O-4Q)

\section{Structure of Phosphatic Microspherules}

A detailed investigation of polished and thin-sectioned specimens revealed the range of internal structure and composition exhibited by microspherules. Microspherules are a consistent feature of the bromalites (Figs. 6-10), but they differ both within and between specimens. Three different types of microspherules were observed: (1) microspherules consisting entirely of large fluorapatite crystals with no discernable internal structure (Fig. 10G); (2) microspherules consisting of relatively thick concentric layers of carbonate fluorapatite microcrystals and amorphous organic carbon (Fig. 10H-10L), with organic carbon in places forming Cshaped rather than O-shaped layers (Fig. 10H-10K) or occupying the center of microspherules (Fig. 10L); and (3) microspherules consisting of thinner and fully concentric layers of carbonate fluorapatite nanocrystals (Fig. 10M, 10N).

Certain features of the microspherules appear to be primary, whereas others are likely secondary in origin. For example, the fully concentric layers (Fig. 10M, 10N) may be a primary structure, forming the core of the best preserved microspherules. The $\mathrm{C}$-shaped concentric layers of organic carbon (Fig. 10H-10J) are likely secondary, resulting from dissolution and re-precipitation of carbonate fluorapatite microcrystals. The organic carbon may represent indigenous kerogen excluded from apatite recrystallization and concentrated in pore space, and/or exogenous bitumen from oil migration. Microspherules without any internal structure (Fig. 10G) were probably cast by secondary crystalline fluorapatite. Some microspherules have an outer rim consisting of palisades of carbonate fluorapatite microcrystals, which evidently grew on the smooth surface of the microspherule, resulting in the formation of an irregular outer surface (arrows in Fig. 6E). This rim, here termed the envelope, probably resulted from secondary growth. The space between microspherules, enveloped or non-enveloped, here termed the inter-microspherule space, is primarily filled with lighter-colored nanocrystalline carbonate fluorapatite or multiple generations of void-filling cement, which is also likely secondary in origin.

\section{DISCUSSION}

\section{Evidence for a Bromalite Interpretation}

Hunt (1992) first coined the term bromalite to encompass specimens representing digestive contents that had either been regurgitated (regurgitalites), expelled as fecal material (coprolites), or were mineralized in situ within the digestive organs following the death of an organism (cololites). Hunt (1992) provided a list of criteria by which bromalites could be identified. Several of the taphonomic and morphological features highlighted by Hunt are evident in the Winneshiek examples and support their interpretation as bromalites. These lines of evidence include: (1) preservational mode and external morphology suggestive of molding by the digestive or excretory organs; (2) inclusions of incompletely digested skeletal elements of prey items; and (3) evidence for liquefaction or loss of cohesion, as might be expected in poorly consolidated fecal material. Although individually these features may not be sufficient to demonstrate a bromalite origin, because they are also present in other biotic or abiotic structures such as concretions, together they provide strong evidence of a bromalite origin.

The high concentration of organic matter present in fecal material provides a substrate for intense microbial activity (Hollocher and

FIG. 6.-Transmitted light photomicrographs of microspherules in thin section, SUI 145141. A) Transverse cross section of a vermiform fossil. B-E) Successive magnifications showing details of microspherules. Magnified areas are marked with labeled rectangles. Arrows highlight microspherules where the outer edge of the envelope is irregular. Red arrow denotes that envelopes of two adjacent microspherules are continuous, attesting the secondary nature of the envelopes. This specimen is also illustrated in Figure 7 and Figure 9A (top specimen). 

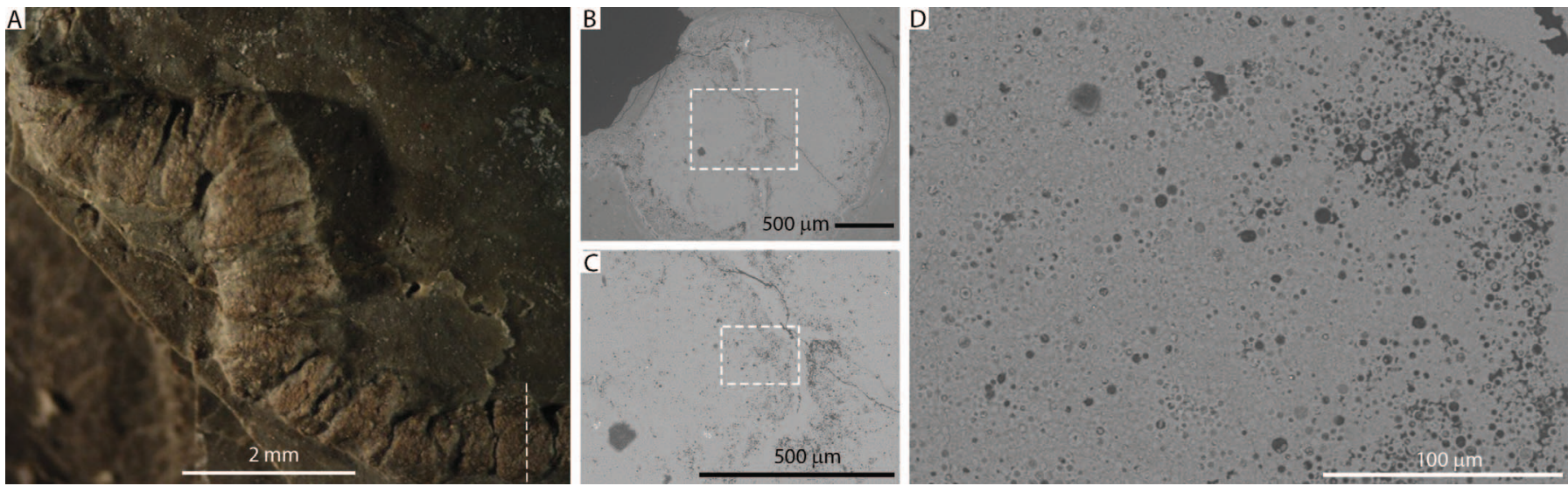

FIg. 8. - Specimen with densely packed microspherules, SUI 145142. A) Reflected light image. White dashed line in lower right indicates where the specimen was cut for thin section preparation. B-D) BSE images. Rectangles in (B) and (C) mark areas magnified in (C) and (D), respectively.

Hollocher 2012), which can promote phosphatization if a sufficient source of phosphate is available (Muscente et al. 2015). Under normal oxic conditions in freshwater or marine settings, the abundance of bicarbonate ions inhibits precipitation of apatite (Allison 1988; Briggs et al. 1993). Under anoxic conditions, however, the metabolic activity of sulfate reducing and other microbes within fecal material can lower the $\mathrm{pH}$ due to release of $\mathrm{CO}_{2}$ and $\mathrm{H}_{2} \mathrm{~S}$ as metabolic byproducts. If the $\mathrm{pH}$ falls sufficiently, then phosphate precipitation is favored (the "calciumphosphate switch"; Briggs and Wilby 1996). Bacterial metabolic activity within fecal pellets can thus generate a microenvironment where phosphate mineralization is favored.

Morphology can serve as evidence for identifying bromalites because both coprolites and cololites commonly reflect the shape and internal structure of the digestive and excretory organs (Amstutz 1958; Hunt 1992). Some morphological features exhibited by the Winneshiek vermiform fossils occur in other examples of bromalites and/or modern fecal material. These include: (1) A shape that is straight and rod-like (Fig. 4A-4C) (Kraeuter and Haven 1970; Vannier et al. 2014; Peel 2015), meandering (Fig. 4D, 4H-4J) (Kraeuter and Haven 1970; Shen et al. 2014), coiled or folded (Fig. 3C-3E) (Williams 1972; McAllister 1985); (2) a circular or sub-circular cross-section (Fig. 3G, 3H) (Kraeuter and Haven 1970; Hollocher and Hollocher 2012; Peel 2015); and (3) a sculpted surface texture consisting of regularly or irregularly spaced transverse corrugations (Fig. 4A-4E) (Kraeuter and Haven 1970; Vannier et al. 2014; Peel 2015) or alternatively a smooth surface texture (Fig. 4I, 4J) (Kraeuter and Haven 1970).

None of the three-dimensionally phosphatized Winneshiek bromalites examined via SEM or in thin section yielded identifiable inclusions that would serve as direct evidence of ingested material, but this is likely a reflection of both the small sample of specimens investigated in this way and the fact that such structures may be easily missed by cross-sections. Some carbonaceous compression specimens or partly phosphatized specimens, however, reveal inclusions that likely represent partially digested prey items (Fig. 4O-4Q). Most of the identifiable material preserved in this way consists of conodonts (Fig. 4O-4Q), either as individual elements or assemblages (Liu et al. 2017), phyllocarids (Briggs et al. 2015, their fig. 3), other small arthropods such as ostracods, and linguloids.
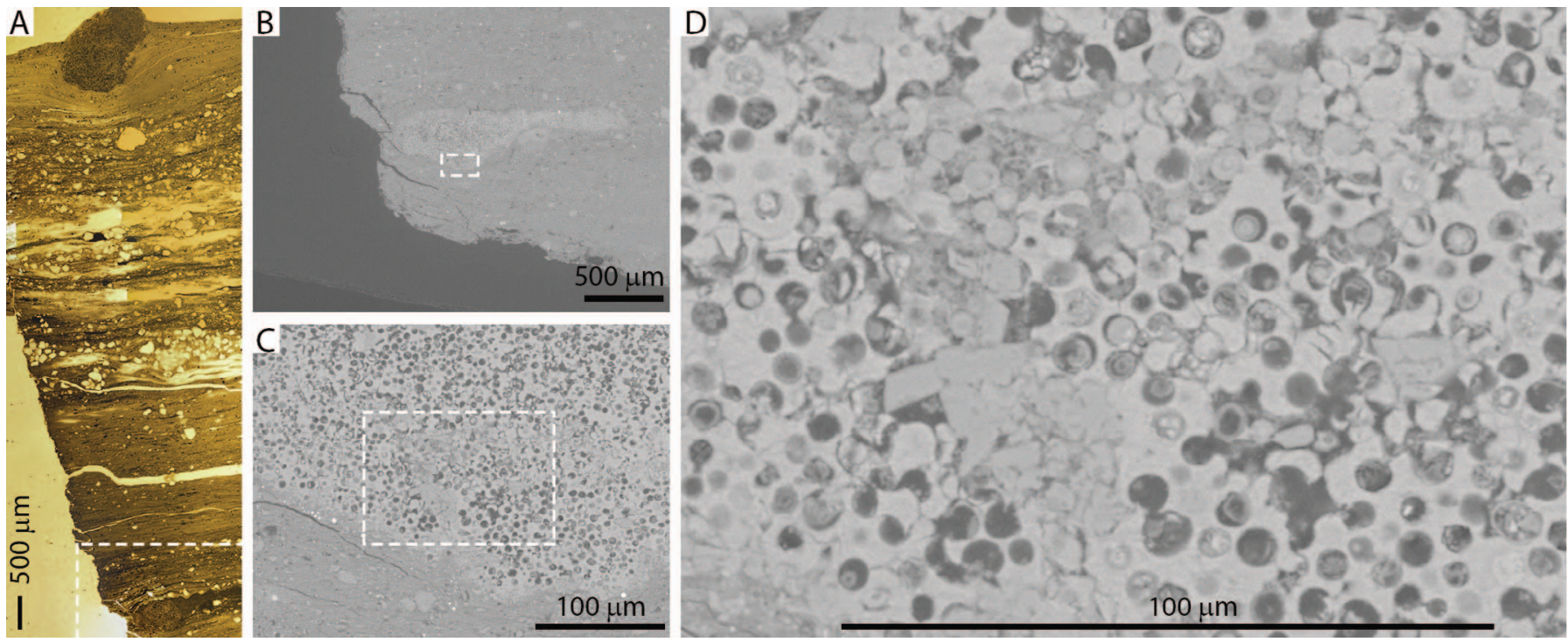

FIG. 9.- Specimens with densely packed microspherules. A) Transmitted light microscopic image of thin section containing two specimens: top specimen (SUI 145141) is also illustrated in Figures 6 and 7, and bottom specimen (rectangle, SUI 145143) is shown here in successive magnifications. B-D) BSE images. Rectangles in (A), (B), and (C) mark areas magnified in (B), (C), and (D), respectively. 

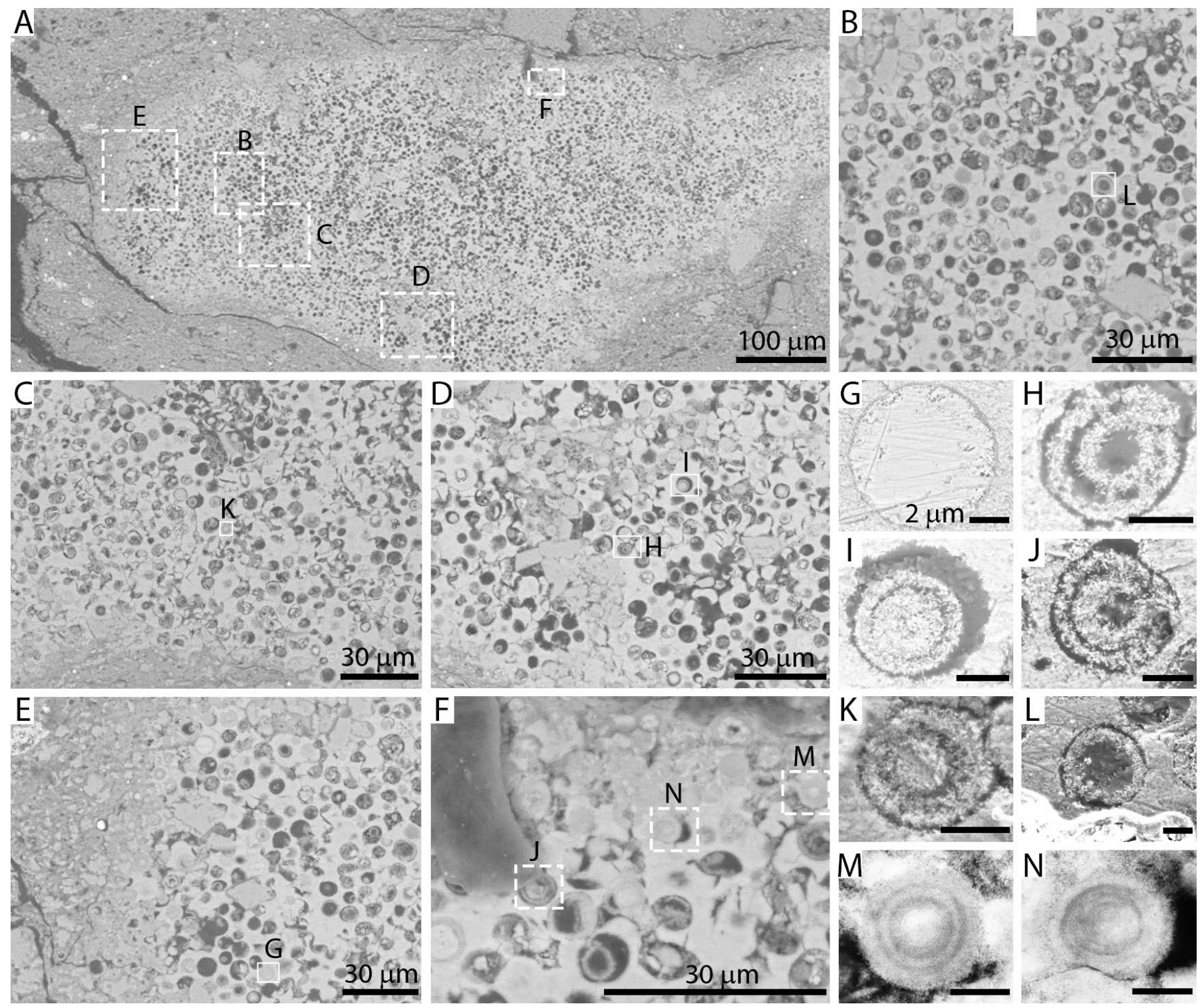

FIG. 10.-SEM images of microspherules in specimen SUI 145143 (also illustrated in Fig. 9, bottom specimen). A) Transverse section of a bromalite exposed during thin section preparation. Labeled boxes mark areas magnified in (B-F). Labeled boxes in (B-F) mark individual microspherules shown in (G-N). Microspherules in (K-L) were imaged in secondary electron mode, while all other SEM pictures were taken in BSE mode. Scale bars in $(\mathrm{G}-\mathrm{N})=2 \mu \mathrm{m}$.

Several Winneshiek bromalites display evidence of loss of cohesion or liquefaction, including examples that show regular vermiform morphologies over a portion of their length and abruptly transition to irregular morphologies, usually with some reduction in three dimensionality (Fig. $5)$.

The various lines of evidence presented above confirm the Winneshiek vermiform fossils as bromalites. The cylindrical to subcylindrical shape rules out regurgitalites, but is consistent with a coprolite rather than cololite origin. Hunt (1992, p. 223) pointed out that 'cololites can only be unequivocally recognized when they are found within the intestinal tract of a fossilized animal.' Even the Winneshiek bromalites preserved as carbonaceous compressions, however, preserve no evidence of an associated organism, such as a conodont apparatus or eurypterid exoskeleton, to identify them unambiguously as cololites. Furthermore, although preserved guts have been recognized in phyllocarids and other crustaceans of the Winneshiek fauna (Briggs et al. 2015, figs. 1.5, 2.7,4.1), they are significantly smaller than most of Winneshiek bromalites described here. However, we cannot rule out the possibility that some Winneshiek bromalites, particularly those with corrugated surface textures (groups 1 and 2: Fig. 4A-4E), may represent circumstances where the phosphatized gut trace, but not the hosting animal, was selectively preserved. The most parsimonious interpretation of the Winneshiek bromalites is that the majority represents coprolites but some may be cololites.

An alternative interpretation of the Winneshiek vermiform fossils is that they represent the phosphatized body fossils or burrows of wormlike animals, but this can be rejected. Although they are three-dimensionally phosphatized and preserve minute details (e.g., microspherules), the vermiform fossils lack any recognizable anatomical features such as a pharynx, teeth, musculature, sclerites, or cuticle fragments. In contrast, the internal structures preserved, including the cross-walls (Fig. 3N) and microspherules (Figs. 6-10), resemble those in coprolites and cololites. Thus, there is no evidence that they represent the body fossils of wormlike animals.

Some living polychaete species produce thin mucous membranes that line tube walls (Richards 1978). This membrane displays a distinctive 

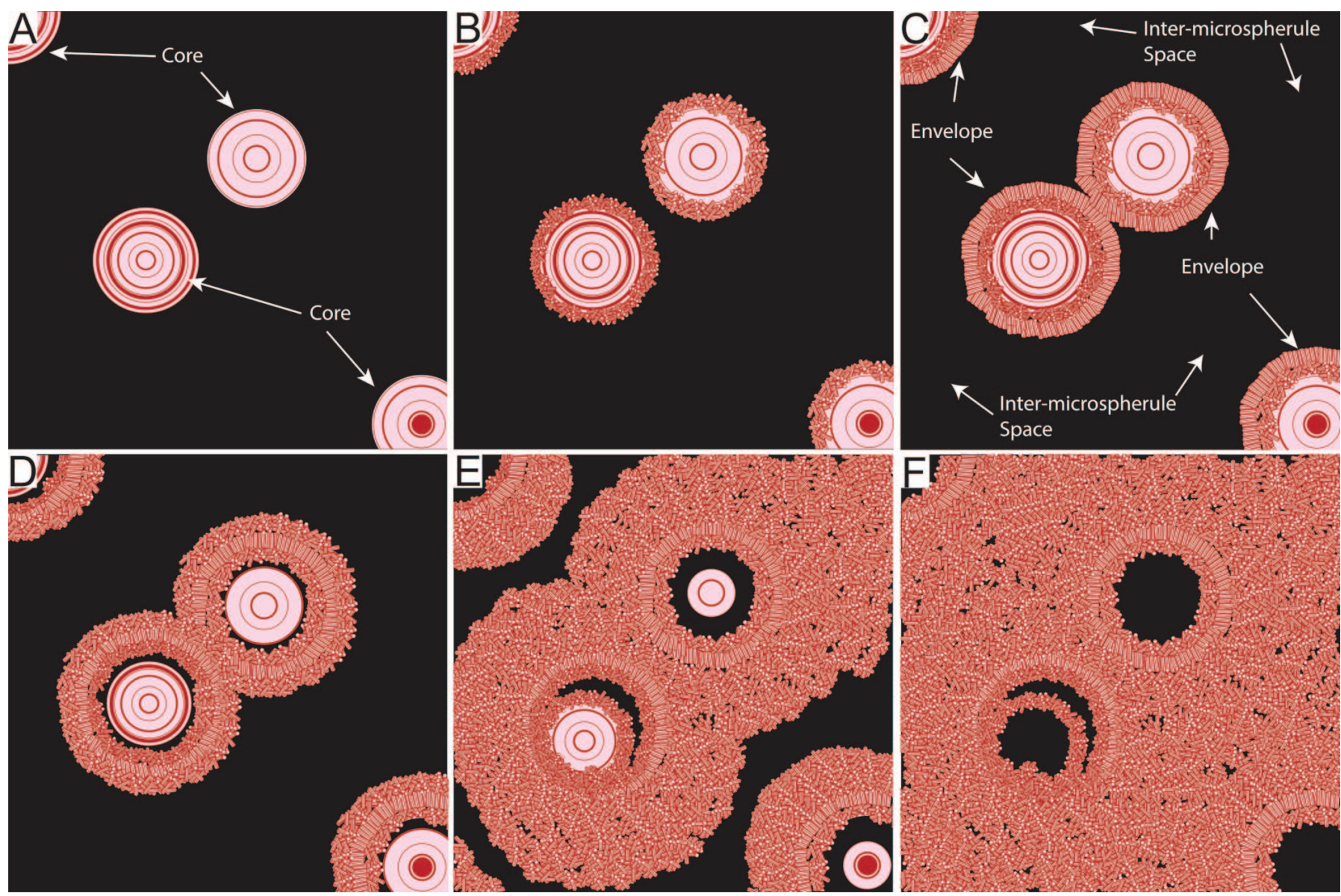

FIG. 11.-Schematic drawing showing paragenetic sequence of secondary mineral precipitation. Illustration assumes biological granule precursor of microspheres. A) Precursor granules with concentric layers. B) Initial nucleation of micro- and nanocrystalline fluorapatite on precursor granules. C) Nucleation and growth of outer envelope. In places, envelopes of two adjacent microspherules are continuous (Fig. 6E, red arrow), attesting the secondary nature of the envelopes. D-E) Nucleation and growth of micro- and nanocrystalline fluorapatite in inter-microspherule space, and dissolution of precursor core. F) Complete disappearance of precursor core, and complete infilling of inter-microspherule space.

chevron-like banding pattern on its outer surface and some modern examples may be irregularly folded. Fossil examples of polychaete tubelinings have been reported from the Eocene of Antarctica (Schweitzer et al. 2005). The banding pattern is superficially similar to the surface texture on some Winneshiek vermiform specimens. However, interpretation as a lined burrow does not explain the presence of microspherules in many of the phosphatized Winneshiek specimens, nor the occurrence of conodont elements within them. A burrow infill should result in phosphate growing centripetally from the tube lining, which is not evident in the specimens, and the straight rod-like morphology of some the vermiform fossils (e.g., Fig. 4A, 4B) is an unlikely feature of polychaete burrows.

The diverse assemblage of Winneshiek bromalites joins a number of other lower Paleozoic bromalite assemblages (e.g., Gilmore, 1992; Aldridge et al. 2006; Shen et al. 2014; Peel 2015). The significant variations in morphology, size, internal component, and external structure of the Winneshiek specimens are partly taphonomic, but may reflect different gut contents and different makers (possible candidates include eurypterids, conodonts, and fishes).

\section{Taphonomy}

Three factors are important to the relative frequency of bromalite phosphatization: transport and accumulation of either fecal material or carcasses with organic-rich gut contents in an appropriate depositional setting, a source of phosphate, and an organic composition that facilitates bacterial metabolism and thus enables the generation of microenvironments conducive to mineralization (Hollocher and Hollocher 2012; Muscente et al. 2015). Preservation of coprolites and cololites most commonly occurs within low-oxygen and low-energy aqueous settings (Hollocher and Hollocher 2012). Such conditions are necessary to prevent rapid destruction of fecal material due to the actions of bioturbators and coprophagous scavengers, and by physical reworking. Low-oxygen conditions also favor microbial sulfate reduction, which drives $\mathrm{pH}$ changes that promote phosphatization (Briggs et al. 1993; Broce et al. 2014; Muscente et al. 2015). The finely laminated, organic-rich character of the Winneshiek Shale combined with the rarity of benthic taxa (only occasional linguloid brachiopods are present; Liu et al. 2006) indicates that it was deposited under dysoxic to anoxic conditions with minimal bioturbation. Under these conditions fecal material and carcasses settled on the bottom where they were shielded from the actions of scavengers, bioturbators, currents, or waves.

The source of phosphate for the Winneshiek bromalites may be the same as that for the mineralized gut contents associated with the arthropod Leanchoilia from the Cambrian Burgess Shale. Butterfield (2002) observed that the phosphatized guts from the Burgess Shale also contain phosphatic microspherules and interpreted them as intracellular structures such as enzyme granules, lipid storage vesicles, and mineral spherites. The 
phosphatic microspherules in Winneshiek bromalites do not seem to have an organic vesicle and the best-preserved ones are characterized by thin concentric layers (Fig. 10M, 10N), analogous to phosphatic granules generated by many living arthropods (Becker et al. 1974; Brown 1982) and other animal taxa (Burton 1972; Howard et al. 1981). In modern arthropods, such as decapod crustaceans, mineralized granules are commonly stored within the tissues lining the digestive organs (Simkiss and Taylor 1994). These structures serve as a storage site for calcium ions used in constructing cuticle (Becker et al. 1974; Corrêa et al. 2002) as well as a means of sequestering toxic metals (Mason and Nott 1981; Pullen and Rainbow 1991). The lining of digestive organs containing these granules is regularly shed and expelled in fecal matter and granules can be present in large quantities within fecal pellets (Simkiss and Taylor 1994; Corrêa et al. 2002). Thus, mineralized granules could have provided an important internal source of calcium phosphate that facilitated the phosphatization of Winneshiek bromalites and also explain the abundance of microspherules in these fossils. The best-preserved microspherules (Fig. 10M, 10N) exhibit an internal structure composed of concentric layers of nanocrystalline phosphate, which resembles the internal structure of mineralized granules produced in the midgut of modern decapod crustaceans (e.g., Becker et al. 1974, figs. 5, 6 and Loret and Devos 1992, figs. 4-6). Many microspherules are poorly preserved, with cavities resulting from dissolution and filled with amorphous organic carbon (Fig. 10H-10L), thus releasing phosphate for bromalite mineralization. Phosphate may also have been derived from other sources, including prey items such as arthropods and conodonts, because phosphate from microspherules does not seem to be sufficient to account for the degree of phosphate mineralization in the fossils.

The presence of microbes in fecal material prior to phosphatization provides an alternative to the mineralized granule interpretation of the microspherules. In contrast to Butterfield's (2002) interpretation of similar microspherule structures in Leanchoilia, Lamboy et al. (1994) and Pesquero et al. (2014) interpreted spherical structures in coprolites as molds of bacteria, suggesting a different link between microstructure and taphonomic process. However, the best-preserved microspherules consist of fully concentric layers (Fig. 10M, 10N), suggesting outward accretionary growth, which is consistent with mineralized granules but inconsistent with hollow coccoidal bacteria. Furthermore, among the many thousands of Winneshiek microspherules observed in this study, none of them have a coherent organic wall and few of them show evidence of deflation and collapse; instead, the organic layers in Winneshiek microspherules are often C-shaped, uneven in thickness, and intragranular in form (Fig. 10H-10L). These microstructural features are in sharp contrast to those of permineralized coccoidal bacteria or organic-walled microfossils, which typically have coherent cell walls with stable thicknesses and various degrees of deformation and deflation (e.g., see phosphatized organic-walled microfossils illustrated in Zabini et al. 2012, fig. 5F). Thus, we favor a phosphatic granule interpretation of the Winneshiek microspherules.

Building upon petrographic observations and the phosphatic granule interpretation described above, Figure 11 illustrates a potential paragenetic and taphonomic sequence to account for the morphological variation evident in the Winneshiek microspherules. In this model, the solid core with fully concentric layers (e.g., Fig. 10M, 10N) is regarded as the primary structure (Fig. 11A). Based on modern analogs, the core probably consisted of amorphous phosphate, which has high but variable solubility depending on the presence of organic molecules and trace elements such as Mg (e.g., Boskey and Posner 1974). The dissolution of the primary core provides phosphate to drive the precipitation of carbonate fluorapatite, which is more stable. For example, nanocrystalline carbonate fluorapatite crystals can be nucleated on the surface of the core (Fig. 11B). This is followed by the outward growth of carbonate fluorapatite crystals to form an outer envelope (Fig. 11C), which is expected to have a relatively smooth inner surface (defined by the outer surface of the core) but an irregular outer surface (defined by crystal terminations). Following the initial dissolution of the core, the space between the envelope and the remaining core can be filled by the precipitation of carbonate fluorapatite (Fig. 11C, 11D), erasing the primary concentric structure. If dissolution of the core proceeds to completion, then the entire core can be cast by carbonate fluorapatite crystals (e.g., Fig. 10G). In many cases, however, the core is partially conserved (Fig. 11E) or incompletely cast by carbonate fluorapatite crystals (Fig. 11F), leaving a C-shaped void or a central void to be filled with amorphous organic carbon. The precipitation of carbonate fluorapatite in the inter-microspherule space finally cements the microspherules (Fig. 11D-11F), leading to a phosphatized bromalite.

\section{The Makers of the Bromalites}

Determining the identity of a bromalite maker is difficult except in cases where specimens are found in direct association with body fossils (Hunt 1992). Exceptions are ichnotaxa such as the microcoprolites Favreina and Palaxius, which are sufficiently distinct in morphology to be recognized as the products of decapod crustaceans (Scoffin 1973; Peckmann et al. 2007). The range of morphologies exhibited by the Winneshiek vermiform fossils - straight or meandering cylindrical structures with surface textures ranging from smooth to corrugatedresemble bromalites that can be produced by a wide variety of taxa (Kraeuter and Haven 1970).

Several features of the Winneshiek bromalites are consistent with an arthropod origin. Densely packed phosphatic granules similar in size and shape to the microspherules occur in the midgut of a variety of arthropod taxa (Hopkin and Nott 1979; Hopkin 1990; Simkiss and Taylor 1994). Three-dimensionally phosphatized structures broadly similar to some Winneshiek bromalites have been found directly associated with arthropod body fossils from the Burgess Shale (Butterfield 2002) and Sirius Passet (Peel 2017). Thus, the eurypterid or other arthropods of the Winneshiek Lagerstätte are plausible makers of the Winneshiek bromalites.

A subset of the Winneshiek bromalites exhibit a concentrically layered internal structure (Fig. 3H). This feature is characteristic of the coprolites of animals with a valvular intestinal tract, a feature frequently found in chordates (Williams 1972; Jain 1983; McAllister 1985). The valvular intestine refers to a coiled epithelial flap that is present within the intestinal tract. This flap increases the surface area of the intestine and thus its absorptive efficiency. Feces passing through the coiled flap are left with an internal structure that resembles a rolled-up scroll, with layers of mucus between the concentric layers of fecal material (Gilmore 1992). Gilmore (1992) identified these types of coprolites in association with agnathans from the Silurian of Ireland. Importantly, it has been proposed that spiral coprolites from the Ordovician Soom Shale, which are broadly similar to some Winneshiek bromalites (e.g., Fig. 3C, 3D), may have been produced by conodonts (Aldridge et al. 2006).

Eurypterids, agnathans, and conodonts are thus plausible candidates for the makers of the Winneshiek bromalites. Conodont apparatuses and elements from the Winneshiek Shale demonstrate that some conodont taxa reached large sizes, with apparatuses spanning more than a centimeter (Liu et al. 2017). Conodont animals have been proposed as makers of bromalites from the Soom Shale, which also contains large conodonts (Aldridge et al. 2006). Eurypterids (Lamsdell et al. 2015b) have also been proposed as potential bromalite makers in the Soom Shale (Aldridge et al. 2006). An ultimate test of these hypotheses rests on the discovery of body fossils associated with Winneshiek bromalites. Regardless of the identities of the makers, the presence of conodont elements within some Winneshiek bromalites is unequivocal evidence for predation during the Great Ordovician Biodiversification Event and, if conodont animals were also the makers, these animals could have been both predators and prey. 


\section{CONCLUSION}

Three-dimensionally preserved bromalites from the Middle Ordovician Winneshiek Lagerstätte in northeastern Iowa are a significant component of the assemblage, being the fourth most abundant category of specimens. The majority of Winneshiek bromalites were phosphatized, a common mode of preservation for bromalites, with a smaller number preserved as carbonaceous compressions. Our examination of the composition, external and internal morphologies, and microstructures of these fossils confirms their bromalitic nature. Evidence for this interpretation includes conodont elements as inclusions (likely the remains of food items) in vermiform specimens, evidence for loss of cohesion consistent with the breakdown of fecal material, external morphology suggestive of molding by digestive and/or excretory organs, a mode of preservation (phosphatization) that is commonly observed in bromalitic material, and the presence of microspherules that probably represent fossilized phosphatic granules in the mid-gut of the makers. Circumstantial evidence (e.g., lack of body fossil preservation in association with bromalites preserved as carbonaceous compressions) also suggests that the Winneshiek bromalites are more likely to be coprolites than cololites. The identity of the makers remains uncertain due to the absence of body fossils in direct association. A suite of arthropods, most likely eurypterids, as well as conodonts and fishes are potential candidates. The presence of conodont inclusions in some bromalites provides evidence for predation during the Great Ordovician Biodiversification Event.

\section{ACKNOWLEDGMENTS}

This work was supported by the National Science Foundation (EAR0921245, 0922054, 1528553), NASA Exobiology and Evolutionary Biology Program (NNX15AL27G), the Paleontological Society, and Virginia Tech Department of Geosciences. Luca Fedele provided valuable assistance with microprobe analysis. Benjamin Gill and Brian Romans provided helpful comments on the manuscript. We thank James D. Schiffbauer, Patrick Orr, and an anonymous reviewer for constructive reviews.

\section{REFERENCES}

Aldridge, R.J., Gabbott, S.E., Siveter, L.J., And Theron, J.N., 2006, Bromalites from the Soom Shale Lagerstätte (Upper Ordovician) of South Africa: palaeoecological and palaeobiological implications: Palaeontology, v. 49, p. 857-871, doi: 10.1111/j.14754983.2006.00570.x

Allison, P.A., 1988, Konservat-Lagerstätten: cause and classification: Paleobiology, v. 14, p. 331-344, doi: 10.1017/S0094837300012082.

Amstutz, G.C., 1958, Coprolites: a review of the literature and a study of specimens from southern Washington: Journal of Sedimentary Research, v. 28, p. 498-508, doi: 10.1306 74D7084E-2B21-11D7-8648000102C1865D.

Becker, G.L., Chen, C.-H., Greenawalt, J.W., and Lehninger, A.L., 1974, Calcium phosphate granules in the hepatopancreas of the blue crab Callinectes sapidus: The Journal of Cell Biology, v. 61, p. 316-326.

Boskey, A.L. And Posner, A.S., 1974, Magnesium stabilization of amorphous calcium phosphate: a kinetic study: Materials Research Bulletin, v. 9, p. 907-916, doi: 10.10 6/0025-5408(74)90169-X.

Briggs, D.E.G., Kear, A.J., Martill, D.M., and Wilby, P.R., 1993, Phosphatization of softtissue in experiments and fossils: Journal of the Geological Society, v. 150, p. 1035 1038, doi: 10.1144/gsjgs.150.6.1035.

Briggs, D.E.G., Liu, H.P., McKay, R.M., AND Witzke, B.J., 2015, Bivalved arthropods from the Middle Ordovician Winneshiek Lagerstätte, Iowa, USA: Journal of Paleontology, v. 89, p. 991-1006, doi: 10.1017/jpa.2015.76.

BRIGGS, D.E.G. AND WILBY, P.R., 1996, The role of the calcium carbonate-calcium phosphate switch in the mineralization of soft-bodied fossils: Journal of the Geological Society, v. 153, p. 665-668, doi: 10.1144/gsjgs.153.5.0665.

Broce, J., Schiffbauer, J.D., Sharma, K.S., Wang, G., and Xiao, S., 2014, Possible animal embryos from the lower Cambrian (Stage 3) Shuijingtuo Formation, Hubei Province, South China: Journal of Paleontology, v. 88, p. 385-394, doi: 10.1666/13-062.

Brown, B.E., 1982, The form and function of metal-containing 'granules' in invertebrate tissues: Biological Reviews, v. 57, p. 621-667, doi: 10.1111/j.1469-185X.1982.tb00375
BurTon, R.F., 1972, The storage of calcium and magnesium phosphates and of calcite in the digestive glands of the Pulmonata (Gastropoda): Comparative Biochemistry and Physiology Part A: Physiology, v. 43, p. 655-663, doi: 10.1016/0300-9629(72)90252-6. Butterfield, N.J., 2002, Leanchoilia guts and the interpretation of three-dimensional structures in Burgess Shale-type fossils: Paleobiology, v. 28, p. 155-171, doi: 10.1666/00 94-8373(2002)028 < 0155:LGATIO $>2.0$. CO 2 .

CorrêA, J.D., Farina, M., And Allodi, S., 2002, Cytoarchitectural features of Ucides cordatus (Crustacea Decapoda) hepatopancreas: structure and elemental composition of electron-dense granules: Tissue and Cell, v. 34, p. 315-325, doi: 10.1016/S004081 6602000101 .

Gilmore, B., 1992, Scroll coprolites from the Silurian of Ireland and the feeding of early vertebrates: Palaeontology, v. 35, p. 319-333.

Hollocher, K. and Hollocher, T.C., 2012, Early processes in the fossilization of terrestrial feces to coprolites, and microstructure preservation, in A.P. Hunt, J. Milàn, S.G. Lucas, and J.A. Spielmann (eds.), Vertebrate Coprolites: New Mexico Museum of Natural History and Science, Albuquerque, New Mexico, p. 79-91.

HoPkIN, S.P., 1990, Critical concentrations, pathways of detoxification and cellular ecotoxicology of metals in terrestrial arthropods: Functional Ecology, v. 4, p. 321-327, doi: $10.2307 / 2389593$

HopkIN, S.P. AND NotT, J.A., 1979, Some observations on concentrically structured, intracellular granules in the hepatopancreas of the shore crab Carcinus maenas (L.): Journal of the Marine Biological Association of the United Kingdom, v. 59, p. 867-877, doi: $10.1017 / \mathrm{S} 0025315400036900$

Howard, B., Mitchell, P.C.H., Ritchie, A., Simkiss, K., and Taylor, M., 1981, The composition of intracellular granules from the metal-accumulating cells of the common garden snail (Helix aspersa): Biochemical Journal, v. 194, p. 507-511, doi: 10.1042/bj1 940507.

Hunt, A.P., 1992, Late Pennsylvanian coprolites from the Kinney Brick Quarry, central New Mexico, with notes on the classification and utility of coprolites: New Mexico Bureau of Mines and Mineral Resources, Bulletin, v. 138, p. 221-229.

JAIN, S.L., 1983, Spirally coiled "coprolites" from the Upper Triassic Maleri Formation, India: Palaeontology, v. 26, p. 813-829.

Kass, M.A., Bedrosian, P.A., Drenth, B.J., Bloss, B.R., McKay, R.M., Liu, H., French, B.M., AND Witzke, B.J., 2013a, Geophysical signatures and modeling results from a buried impact structure in Decorah, Iowa, USA: American Geophysical Union Fall Meeting, Abstract P34C-04

Kass, M.A., Bedrosian, P.A., Drenth, B.J., Bloss, B.R., McKay, R.M., Liu, H., French, B.M., AND WITZKE, B.J., 2013b, Modeling and inversion results from airborne geophysics over a buried impact structure in Decorah, Iowa, USA: Geological Society of America Abstracts with Programs, v. 45(7), p. 485.

Korochantseva, E.V., Trieloff, M., Lorenz, C.A., Buykin, A.I., Ivanova, M.A., Schwarz, W.H., Hopp, J., And Jessberger, E.K., 2007, L-chondrite asteroid breakup tied to Ordovician meteorite shower by multiple isochron ${ }^{40} \mathrm{Ar}-{ }^{39} \mathrm{Ar}$ dating: Meteoritics and Planetary Science, v. 42, p. 113-130, doi: 10.1111/j.1945-5100.2007.tb00221.x.

Kraeuter, J. and Haven, D.S., 1970, Fecal pellets of common invertebrates of lower York River and lower Chesapeake Bay, Virginia: Chesapeake Science, v. 11, p. 159-173.

Lamboy, M., Rao, V.P., Ahmed, E., And Azzouzi, N., 1994, Nannostructure and significance of fish coprolites in phosphorites: Marine Geology, v. 120, p. 373-383, doi: 10.1016/002 5-3227(94)90068-X

Lamsdell, J.C., Briggs, D.E.G., Liu, H.P., Witzke, B.J., and McKay, R.M., 2015a, A new Ordovician arthropod from the Winneshiek Lagerstätte of Iowa (USA) reveals the ground plan of eurypterids and chasmataspidids: The Science of Nature, v. 102, p. 63, doi: 10.1007/s00114-015-1312-5.

Lamsdell, J.C., Briggs, D.E.G., Liu, H.P., Witzke, B.J., and McKay, R.M., 2015b, The oldest described eurypterid: a giant Middle Ordovician (Darriwilian) megalograptid from the Winneshiek Lagerstätte of Iowa: BMC Evolutionary Biology, v. 15, p. 1, doi: 10.11 86/s12862-015-0443-9.

Lamsdell, J.C., LoDuca, S.T., Gunderson, G.O., Meyer, R.C., and Briggs, D.E.G., 2017, A new Lagerstätte from the Late Ordovician Big Hill Formation, Upper Peninsula, Michigan: Journal of the Geological Society, v. 174, p. 18-22, doi: 10.1144/jgs2016-0

Liu, H., McKay, R.M., Witzke, B.J., And Briggs, D.E.G., 2009, The Winneshiek Lagerstätte, Iowa, USA and its depositional environments: Geological Journal of China Universities, v. 15 , p. $285-289$

Liu, H.P., Bergström, S.M., Witzke, B.J., Briggs, D.E.G., McKay, R.M., and Ferretti, A., 2017, Exceptionally preserved conodont apparatuses with giant elements from the Middle Ordovician Winneshiek Konservat-Lagerstätte, Iowa, USA: Journal of Paleontology, v. 91, p. 493-511, doi: 10.1017/jpa.2016.155.

Liu, H.P., McKay, R.M., Young, J.N., Witzke, B.J., McVey, K.J., and Liu, X., 2006, A new Lagerstätte from the Middle Ordovician St. Peter Formation in northeast Iowa, USA: Geology, v. 34, p. 969-972, doi: 10.1130/G22911A.1.

Loret, S.M. And Devos, P.E., 1992, Structure and possible functions of the calcospheriterich cells $\left(\mathrm{R}^{*}\right.$ cells) in the digestive gland of the shore crab Carcinus maenas: Cell and Tissue Research, v. 267, p. 105-111, doi: 10.1007/BF00318696.

Mason, A.Z. AND NotT, J.A., 1981, The role of intracellular biomineralized granules in the regulation and detoxification of metals in gastropods with special reference to the marine prosobranch Littorina littorea: Aquatic Toxicology, v. 1, p. 239-256. 
McAllister, J.A., 1985, Reevaluation of the formation of spiral coprolites: University of Kansas, Paleontological Contributions, v. 114, p. 1-12.

McKay, R., Liv, H., Witzke, B.J., French, B.M., and Briggs, D.E.G., 2011, Preservation of the Middle Ordovician Winneshiek Shale in a probable impact crater: Geological Society of America Abstracts with Programs, v. 43(5), p. 189.

McKay, R.M., Liu, H.P., Witzke, B.J., And French, B.M., 2010, Geologic setting of the Winneshiek Lagerstätte-Decorah, Iowa: Geological Society of America Abstracts with Programs, v. 42(2), p. 89.

Muscente, A.D., Hawkins, A.D., And XiaO, S., 2015, Fossil preservation through phosphatization and silicification in the Ediacaran Doushantuo Formation (South China): a comparative synthesis: Palaeogeography Palaeoclimatology Palaeoecology, v. 434, p. 46-62, doi: 10.1016/j.palaeo.2014.10.013.

Muscente, A.D., Schiffbauer, J.D., Broce, J., Laflamme, M., O’Donnell, K., Boag, T.H., Meyer, M., Hawkins, A.D., Huntley, J.W., McNamara, M., MacKenzie, L.A., Stanley JR., G.D., Hinman, N.W., Hofmann, M.H., and XiaO, S., 2017, Exceptionally preserved fossil assemblages through geologic time and space: Gondwana Research, v. 48, p. 164 188, doi: 10.1016/j.gr.2017.04.020.

Muscente, A.D. And XiaO, S., 2015, Resolving three-dimensional and subsurficial features of carbonaceous compressions and shelly fossils using backscattered electron scanning electron microscopy (BSE-SEM): PALAIOS, v. 30, p. 462-481, doi: 10.2110/palo.201 4.094

NowaK, H., Harvey, T.H.P., Liu, H.P., McKay, R.M., and Servais, T., 2017, Exceptionally preserved arthropodan microfossils from the Middle Ordovician Winneshiek Lagerstätte, Iowa, USA: Lethaia, doi: 10.1111/let.12236.

Peckmann, J., Senowbari-Daryan, B., Birgel, D., and Goedert, J., 2007, The crustacean ichnofossil Palaxius associated with callianassid body fossils in an Eocene methane-seep limestone, Humptulips Formation, Olympic Peninsula, Washington: Lethaia, v. 40, p. 273-280, doi: 10.1111/j.1502-3931.2007.00026.x

Peel, J.S., 2015, Bromalites from the Cambrian (Series 2 and 3) of North Greenland: GFF, v. 137 , p. 181-194, doi: $10.1080 / 11035897.2014 .995217$.

PeEL, J.S., 2017, Mineralized gutfills from the Sirius Passet Lagerstätte (Cambrian Series 2) of North Greenland: GFF, v. 139, p. 83-91, doi: 10.1080/11035897.2016.1260051.

Pesquero, M.D., Souza-Egipsy, V., Alcalá, L., Ascaso, C., and Fernández-Jalvo, Y., 2014 Calcium phosphate preservation of faecal bacterial negative moulds in hyaena coprolites: Acta Palaeontologica Polonica, v. 59, p. 997-1005, doi: 10.4202/app.2012.0067.

Pullen, J.S.H. AND RainBow, P.S., 1991, The composition of pyrophosphate heavy metal detoxification granules in barnacles: Journal of Experimental Marine Biology and Ecology, v. 150, p. 249-266, doi: 10.1016/0022-0981(91)90070-D.

Richards, K.S., 1978, Chapter 2, Epidermis and cuticle, in P.J. Mill (ed.), Physiology of Annelids: Academic Press, London, p. 33-62.

Schiffbauer, J.D., Xiao, S., Cai, Y., Wallace, A.F., Hua, H., Hunter, J., Xu, H., Peng, Y., and Kaufman, A.J., 2014, A unifying model for Neoproterozoic-Palaeozoic exceptional fossil preservation through pyritization and carbonaceous compression: Nature Communications, v. 5, doi: $10.1038 /$ ncomms6754
Schiffbauer, J.D., Xiao, S., Sen Sharma, K., and Wang, G., 2012, The origin of intracellular structures in Ediacaran metazoan embryos: Geology, v. 40, p. 223-226, doi: $10.1130 / \mathrm{G} 32546.1$

Schmitz, B., Harper, D.A., Peucker-Ehrenbrink, B., Stouge, S., Alwmark, C., Cronholm, A., Bergström, S.M., Tassinari, M., and Xiaofeng, W., 2008, Asteroid breakup linked to the Great Ordovician biodiversification event: Nature Geoscience, v. 1, p. 49-53, doi: 10.1038/ngeo.2007.37

Schweitzer, C.E., Feldmann, R.M., Marenssi, S., and Waugh, D.A., 2005, Remarkably preserved annelid worms from the La Meseta Formation (Eocene), Seymour Island, Antarctica: Palaeontology, v. 48, p. 1-13, doi: 10.1111/j.1475-4983.2004.00440.x.

Scoffin, T.P., 1973, Crustacean faecal pellets, Favreina, from the Middle Jurassic of Eigg, Inner Hebrides: Scottish Journal of Geology, v. 9, p. 145-146.

Shen, C., Pratt, B.R., and Zhang, X.-G., 2014, Phosphatized coprolites from the middle Cambrian (Stage 5) Duyun fauna of China: Palaeogeography, Palaeoclimatology, Palaeoecology, v. 410, p. 104-112, doi: 10.1016/j.palaeo.2014.05.035.

Simkiss, K. AND TAYLOR, M.G., 1994, The formation of apatite from crab faecal pellets: Journal of the Marine Biological Association of the United Kingdom, v. 74, p. 459-462, doi: $10.1017 / \mathrm{S} 0025315400039497$.

Tang, Q., Pang, K., Yuan, X., And XIAO, S., 2017, Electron microscopy reveals evidence for simple multicellularity in the Proterozoic fossil Chuaria: Geology, v. 45, p. 75-78, doi: $10.1130 / \mathrm{G} 38680.1$

Van Roy, P., Briggs, D.E.G., and Gaines, R.R., 2015, The Fezouata fossils of Morocco; an extraordinary record of marine life in the Early Ordovician: Journal of the Geological Society, v. 172, p. 541-549, doi: 10.1144/jgs2015-017.

Vannier, J., Liu, J., Lerosey-Aubrit, R., Vinther, J., and Daley, A.C., 2014, Sophisticated digestive systems in early arthropods: Nature Communications, v. 5, p. 1-9, doi: 10.103 $8 /$ ncomms 4641 .

WiLliams, M.E., 1972, The origin of "spiral coprolites": The University of Kansas Paleontological Contributions, v. 59, p. 1-19.

Witzke, B.J., McKay, R.M., Liu, H.P., And Briggs, D.E.G., 2011, The Middle Ordovician Winneshiek Shale of Northeast Iowa - correlation and paleogeographic implications: Geological Society of America Abstracts with Programs, v. 43(5), p. 315

Young, G.A., Rudkin, D.M., Dobrzanski, E.P., Robson, S.P., Cuggy, M.B., Demski, M.W., And Thompson, D.P., 2013, Great Canadian Lagerstätten 3, Late Ordovician KonservatLagerstätten in Manitoba: Geoscience Canada, v. 39, p. 201-213.

Young, G.A., Rudkin, D.M., Dobrzanski, E.P., Robson, S.P., and Nowlan, G.S., 2007, Exceptionally preserved Late Ordovician biotas from Manitoba, Canada: Geology, v. 35 , p. 883-886, doi: 10.1130/G23947A.1.

Zabini, C., Schiffbauer, J.D., Xiao, S., and Kowalewski, M., 2012, Biomineralization, taphonomy, and diagenesis of Paleozoic lingulide brachiopod shells preserved in silicified mudstone concretions: Palaeogeography, Palaeoclimatology, Palaeoecology, v. 326-328, p. 118-127, doi: 10.1016/j.palaeo.2012.02.010.

Received 12 June 2017; accepted 18 November 2017. 